\title{
Weathering of volcanic tuff rocks caused by moisture expansion
}

\author{
Wanja Wedekind · Rubén López-Doncel • \\ Reiner Dohrmann • Mathias Kocher • \\ Siegfried Siegesmund
}

Received: 18 September 2012/ Accepted: 29 November 2012/Published online: 28 December 2012

(C) The Author(s) 2012. This article is published with open access at Springerlink.com

\begin{abstract}
Moisture expansion in natural building stones is considered one of the most important factors affecting their weathering and deterioration. The processes that may be responsible for the expansion under determinate relative humidity (hygric dilatation) and water-saturated conditions (hydric dilatation) are generally attributed to the presence of swellable clay minerals. In contrast to this assumption, our investigations show that moisture expansion also takes place in volcanic tuff building stones almost free from clay minerals. To provide a deeper understanding of the processes, swelling and deterioration were performed on 14 volcanic tuffs used as important building stones of different ages, compositions and weathering stages from Mexico, Germany and Hungary. The investigations undertaken include extensive chemical, petrophysical and fabric analyses. The samples show a wide range of effective porosity, microporosity, capillary water absorption, moisture expansion, and CEC values. High moisture expansion does not seem to depend on clay mineral content alone. We also observed that there is no significant effect on dilatation
\end{abstract}

W. Wedekind $(\bowtie) \cdot$ S. Siegesmund

Geoscience Centre of the University Goettingen,

Goettingen, Germany

e-mail: wwedekind@gmx.de

R. López-Doncel

Geological Institute, Autonomous University of San Luis Potosí,

San Luis Potosí, Mexico

R. Dohrmann

Federal Institute for Geosciences and Natural Resources (BGR), Hanover, Germany

M. Kocher

Department of Restoration, Art Technology and Conservation Science, Technical University of Munich, Munich, Germany if clay minerals are present but only form a thin coat on the outer shell of bigger pores. Moreover, we identified a correlation between microporosity, average pore radius and moisture expansion. The investigations highlight the fact that moisture expansion cannot only be attributed to swellable clay minerals, and suggest that the presence and accumulation of micropores and their average radius and distribution play an important role for non-clay associated swelling intensity, which can most probably be attributed to the disjoining pressure.

Keywords Weathering of tuffs - Hygric expansion . Hydric expansion · Clay mineralogy · Microporosity · Disjoining pressure

\section{Introduction}

Volcanic rocks have been an important natural building material since the beginning of time. Their use varied from monumental sculptures in antique cultures to recent modern buildings all over the world. The reason these rocks are so appreciated as natural building stones is mainly due to three facts; firstly, because some of these rocks and, in particular, tuffs, are relatively soft and easy to work with. Secondly, they are available worldwide, because tuff rocks are present in many places and all geological times; and thirdly, tuff rocks exist in a great assortment of colours, composition, grain size, sorting and textures, which makes these rocks very attractive for construction and artwork (Fig. 1).

From a geological point of view, tuffs are volcanic rocks with matrix grain sizes ranging from fine clay minerals up to silt-sized material (matrix normally present in ash form), in which sand, crystals or rock fragments up to gravel and 


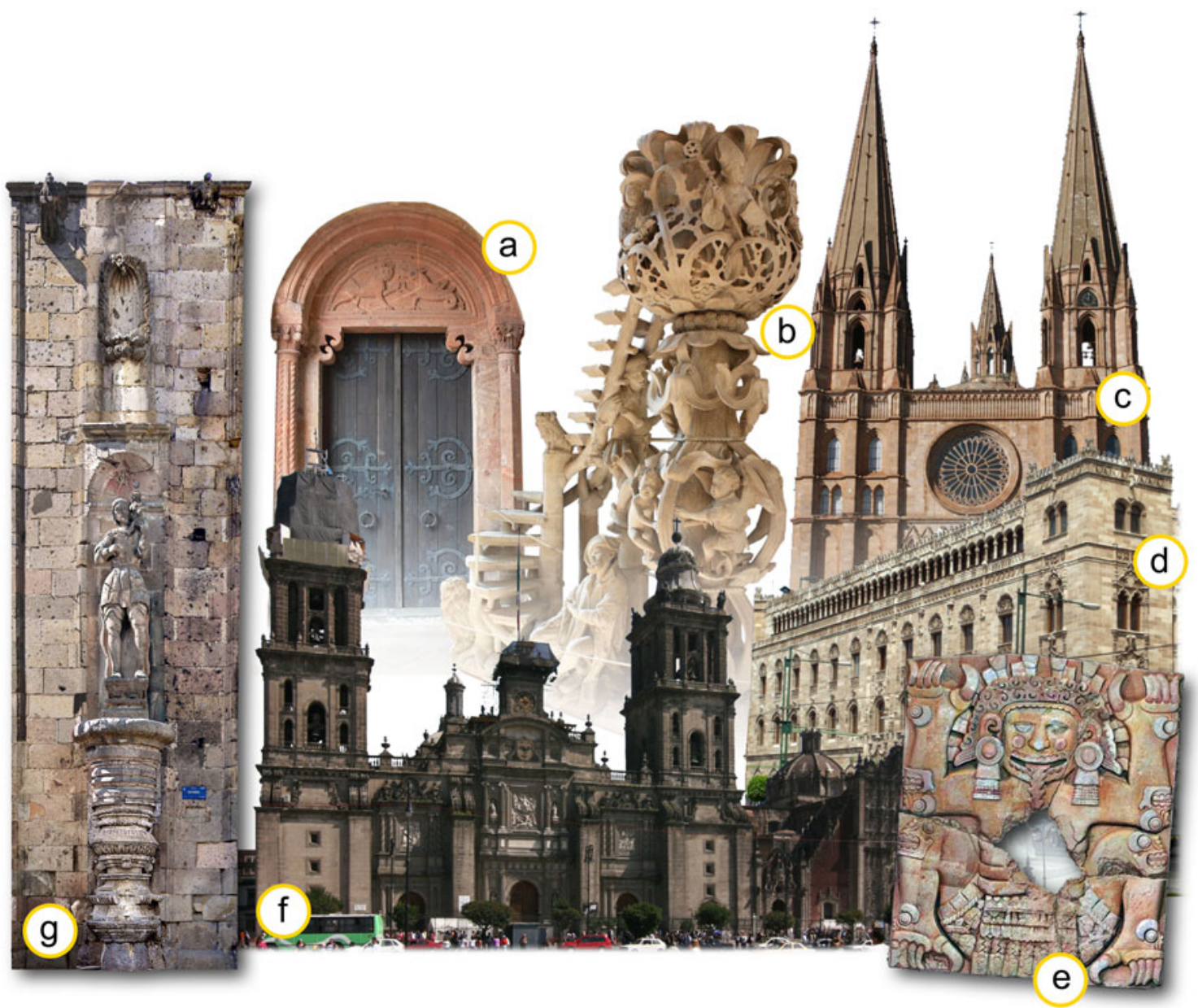

Fig. 1 Volcanites used as building stones and for artwork: a Rochlitz Tuff, RP (portal at monastery Wechselburg/Germany), b Hilbersdorf Tuff, HD (tulip pulpit cathedral of Freiberg/Germany), c Cantera Rosa San Miguel el Alto, CR (cathedral Arandas/Mexico), d Blanca de Pachuca Tuff, BP (Palacio Postal Mexico-City), e Tenayocátetl

block-sized clasts and lithics (also known as lapilli), as well as volcanic blocks and bombs, are embedded. The arrangement between these tuff components and the lithology itself opens a very wide spectrum of porosities, very different fabrics (Fischer 1961; Le Maitre et al. 2004) and normally large amounts of clay minerals in the matrix. However, at the same time, these characteristics cause tuffs to be less resistant to deterioration, particularly if they are exposed to moisture and humidity (Steindlberger 2003; Ruedrich et al. 2011; Timothy et al. 2011).

Deterioration on buildings is often concentrated in areas affected by temporary moisture infiltration and leads to different damage phenomena (Fig. 2). Moisture expansion is clearly recognized as one of the most important factors contributing to the weathering and deterioration of building rocks (Ruedrich et al. 2011; Weiss et al. 2004), and this is mostly associated with the swelling and shrinking of clay minerals (Schuh 1987; De La Calle and Suquet 1988;
Tuff, TY (Aztec sculpture Tlatecuhtli, Templo Mayor, Mexico-City), f Chiluca, $\mathrm{CH}$, and Cantera gris de los Remedios, GR (cathedral of Mexico-City), g Cantera Amarilla Tuff, CA (Santa Monica Church, Guadalajara/Mexico)

Snethlage et al. 1995; Jimenez Gonzalez and Scherer 2004; Dixon and Weed 1989; Moore and Reynolds 1997; Graf et al. 1995). The intensity of moisture expansion varies markedly depending on the type of stone. In general, volcanic stones, and primarily tuffs, have a wide range of moisture expansion, which, as measured in this study, can reach a dilatation of up to $6 \mathrm{~mm} / \mathrm{m}$ (Fig. 3).

Although the swellability of the clay minerals plays a decisive role in the weathering of building rocks, the different processes that cause this phenomenon, and the question as to which is the main process during the observed swelling, are still under discussion. In principle, there are two mechanisms that can act inside and between the clay minerals; the inner-crystalline (intra-crystalline) (Madsen and Mueller-Vonmoos 1989) or the osmotic (inter-crystalline) swelling (Heim 1990; Auras and Steindlberger 2005). To understand these mechanisms, it is very important to have measured the amount and type of 

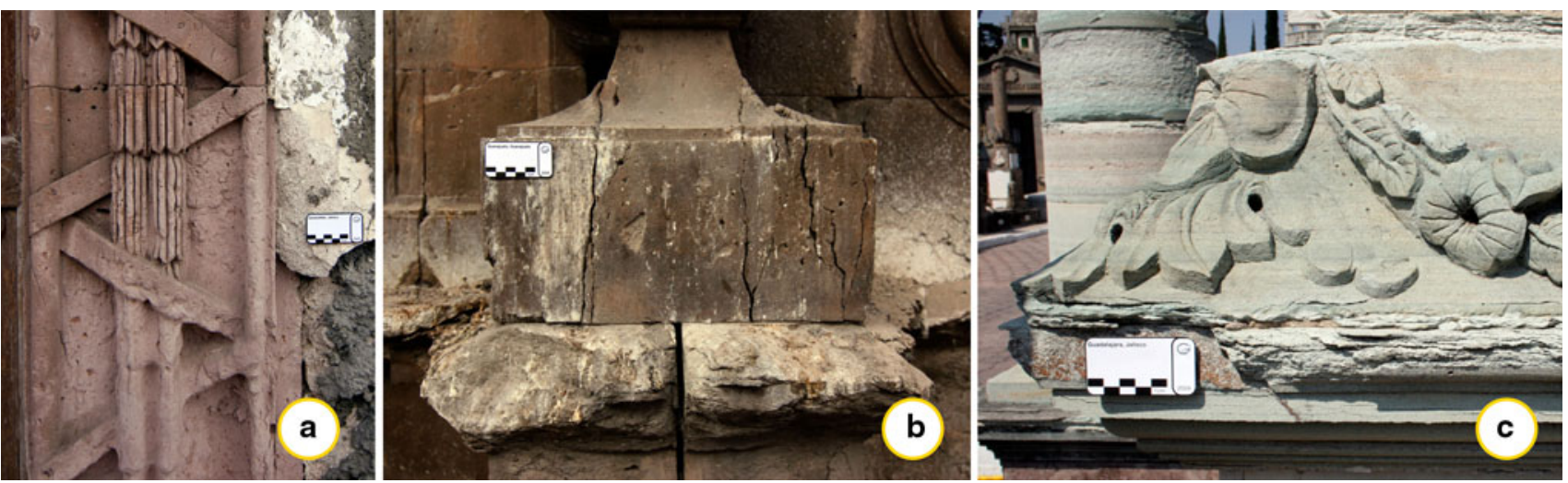

Fig. 2 Different damage phenomena observable in tuffs associated with moisture expansion of the rock material. a Back weathering of Cantera Rosa Tuff (CR) of San Miguel de Alto, Jalisco/Mexico. b Extensive cracking parallel to the bedding of the Bufa Tuff (BT) in Guanajuato/Mexico. c Scaling parallel to the bedding of Loseros Tuff (LS) found in Guadalajara/Mexico

Fig. 3 Swelling- and moisture expansion of building stones (data from different authors and from this study). Modified from Kocher (2005): Granite, marble und sandstone I from

Hockmann and Kessler (1950), from Snethlage (1984),

limestone from Lukas (1990), sandstones II from Schuh (1987), sandstones III from Snethlage and Wendler (1997), concretes from Wesche (1977), mudstones from Madsen (1976) and Madsen and Nueesch (1990)

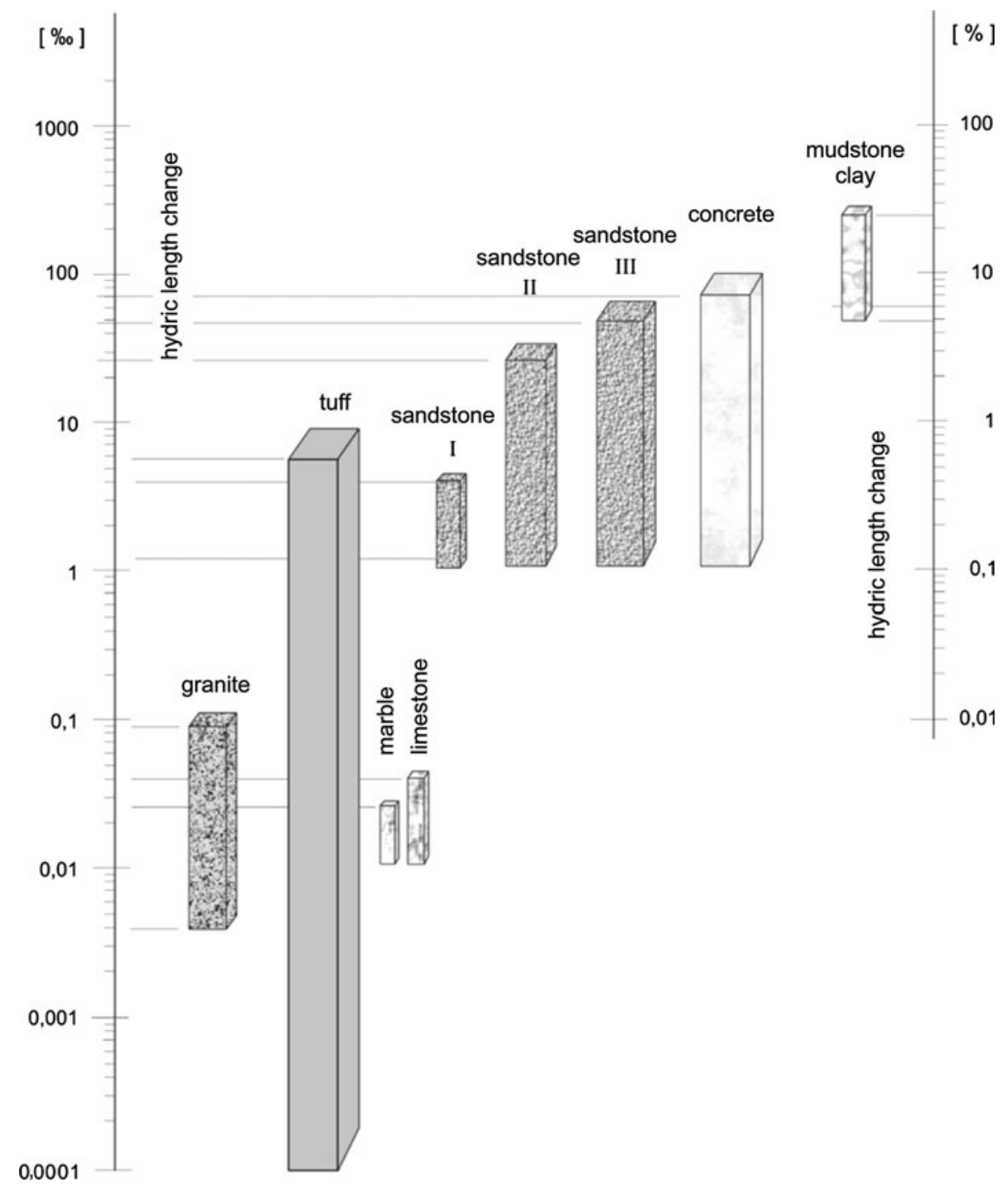

clay minerals present, because 1:1 and 2:1 layered clay minerals can condition this effect through their cationexchange capacity and the water uptake provoked by the electrolyte concentration in water that caused an osmotic swelling (Madsen and Muller-Vonmoos 1988, 1989; Heim 1990). There is also a "non-clay associated" swelling type 
known as disjoining pressure, which is similar to osmotic swelling and related to the electrolyte concentration of a solution (Derjaguin and Obukov 1936). This swelling type is more dependent on the size and amount of micropores in the rock, as well as on the presence of lithoclasts in sandstone (Ruedrich et al. 2011).

The disjoining pressure $\left(\Pi_{d}\right)$ arises from an interaction between two flat and parallel surfaces. The value of the disjoining pressure can be calculated as the derivative of the Gibbs energy of interaction per unit area with respect to distance. This energy, also known as free energy, is defined as a thermodynamic potential that measures the process-initiating work obtainable from a thermodynamic system at a constant temperature and pressure (Greiner et al. 1995). The disjoining pressure will be affected when the distance between them is less than two times the thickness of adsorbed moisture on a free surface, where the force needed to keep the forced distance is determined by the so-called "disjoining pressure equation" (Nielsen 1994).

Ruedrich et al. (2011) presented a detailed overview of the different types and causes of the moisture expansion. Whatever the cause of the moisture expansion may be, the water uptake and distribution into the rock is the principal mechanism allowing water (moisture and humidity) to interact with the clay minerals present and is only realizable through the porosity. The porosity, therefore, is one of the most important parameters that must be known and determined.

As seen above, microporosity plays an important role not only for the disjoining pressure, but also because, by reaching the critical pore size of $5 \mu \mathrm{m}$, the pore water is trapped and cannot be drained out of the stone (Larsen and Cady 1969). Pore water hosted in the micropores can contribute to the dissolution of certain minerals in the matrix or to the acceleration of the swelling of clay minerals. Once the rock has been affected by internal weathering, the effective porosity ratio has been increased (Tugrul 2004), allowing major water circulation in all its variants into the rock.

This phenomenon also occurs with all the other types of porosity, and their size and distribution within the rock are similarly decisive for stone durability (Benavente et al. 2004; Siegesmund and Duerrast 2011).

The factors clay mineral content and porosity are two parameters that are certainly important in tuff rocks, because they can occur in a wide range of amounts and forms. Likewise, the chemical and mineralogical composition of tuff rocks is very diverse, which also influences their durability and resistance against weathering and deterioration.

The main goal of this investigation is to contribute to the existing knowledge about moisture expansion of tuffs used as building stones. This study used 14 important volcanic tuff rocks used in construction from Germany, Hungary, and Mexico of different ages, compositions, and states of weathering. Hydric and hygric wetting experiments conducted on the tuff rocks, as well as chemical and mineralogical analyses of the clay fraction, which included XRD (X-ray diffraction) of oriented slides and CEC analysis, were performed in order to determine the total amount of swellable clay minerals and to clarify what role the presence of 1:1 or 2:1 layered clay minerals plays in tuff and its relationship to moisture expansion.

\section{Examined rock material}

Fourteen total volcanic tuffs were investigated in this study, while eight tuffs were investigated in greater detail because of their particular properties. From these eight volcanites, four are from Mexico: Cantera Blanca Tuff (BP), Tenayocátetl Tuff (TY) Bufa Tuff (BT) and Cantera Amarilla Tuff (CA); three are from Germany: Habichtswald Tuff (HW), Rochlitz Tuff (RP) and Hilbersdorf Tuff (HD); and one from Hungary: Eger-Demjén Tuff (ED) (Figs. 4, 5).

Additionally, another six volcanites were investigated: Weibern Tuff (WB), Loseros Tuff (LS), Chiluca Tuff (CH), Gris de los Remedios Tuff (GR), Cantera Rosa Tuff (CR), and Cantera Formación Tuff (CF).

\section{Methods}

The open (effective) porosity, as well as the density, of sixand-a-half centimetre long cubic stone samples were measured using hydrostatic weighting (DIN 52 102). The water-saturated mass, the buoyancy mass of the samples measured after water saturation under vacuum, and the dry sample mass were used to calculate the porosity.

The moisture expansion by hygric and hydric wetting of the volcanic rocks was determined using cylindrical samples $(\varnothing 15 \mathrm{~mm} \times 100 \mathrm{~mm})$. To evaluate hydric moisture expansion, these stone cylinders were measured under water-saturated conditions. The hygric moisture expansion was performed in a special measurement environment connected to a climate chamber. The moisture expansion was measured step by step, beginning from $20 \%$ relative humidity (RH) and gradually increasing up to $95 \%$ at a constant temperature of $30{ }^{\circ} \mathrm{C}$. For water-saturated conditions, the samples were completely immersed in distilled water. The resolution of the displacement transducer is $0.1 \mu \mathrm{m}$ and the accuracy is about $0.5 \mu \mathrm{m}$. The measurements were carried out on all samples parallel to the $X, Y$, and $Z$ axes. 

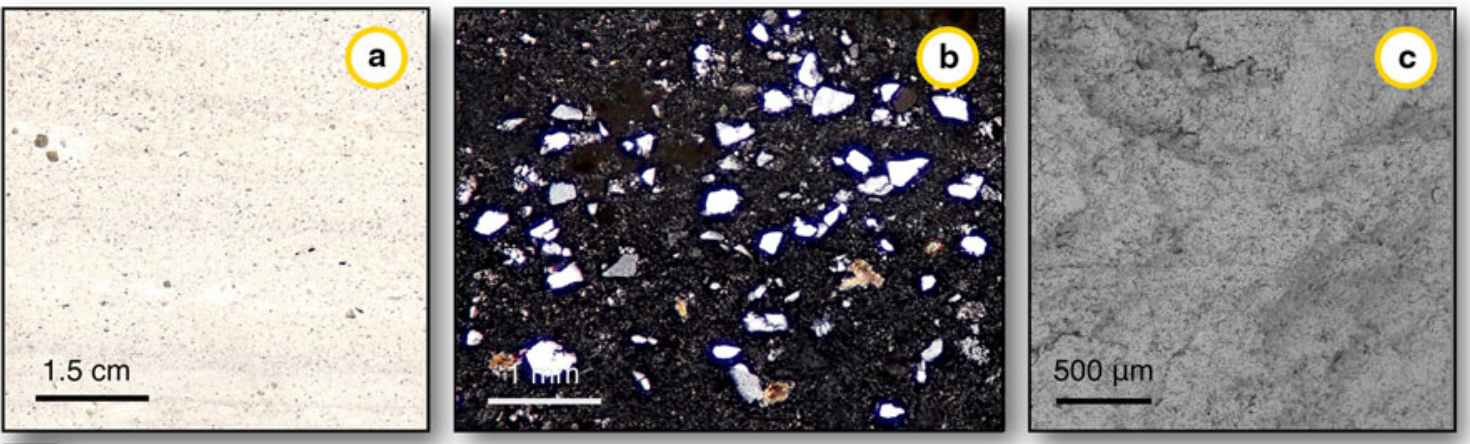

BP Cantera Blanca Tuff (Blanca Pachuca), Hidalgo / Mexico
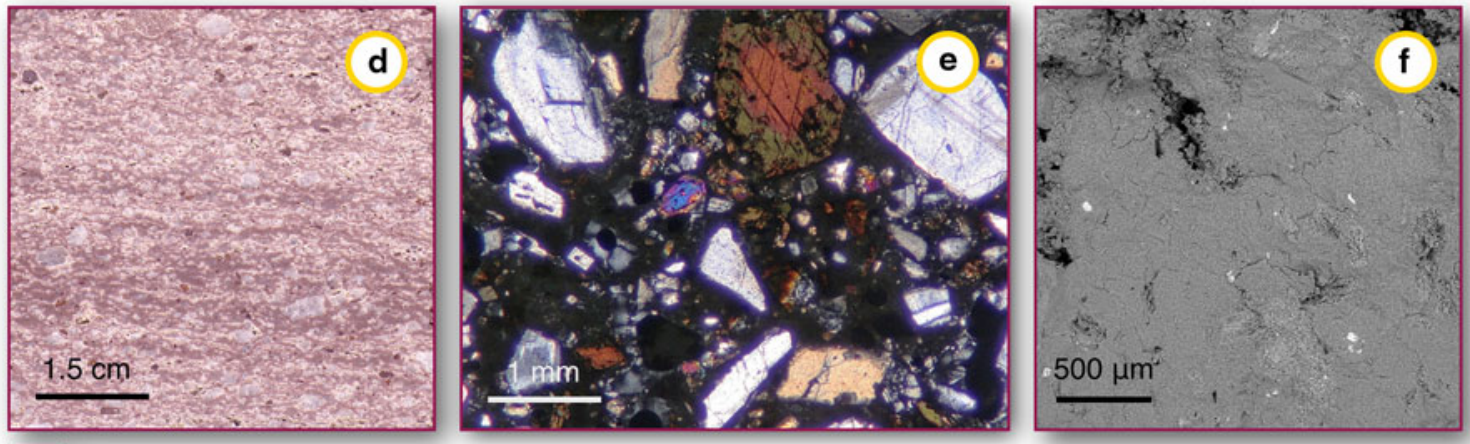

TY Tenayacátetl Tuff, Estado de México / Mexico
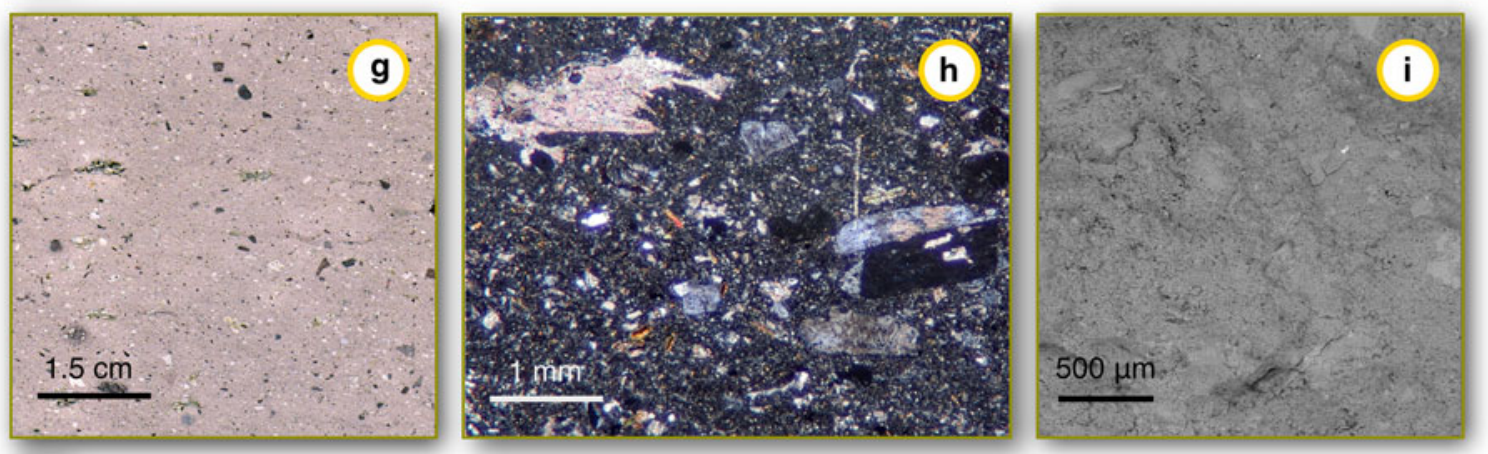

\section{BT Bufa Tuff, Guanajuato / Mexico}
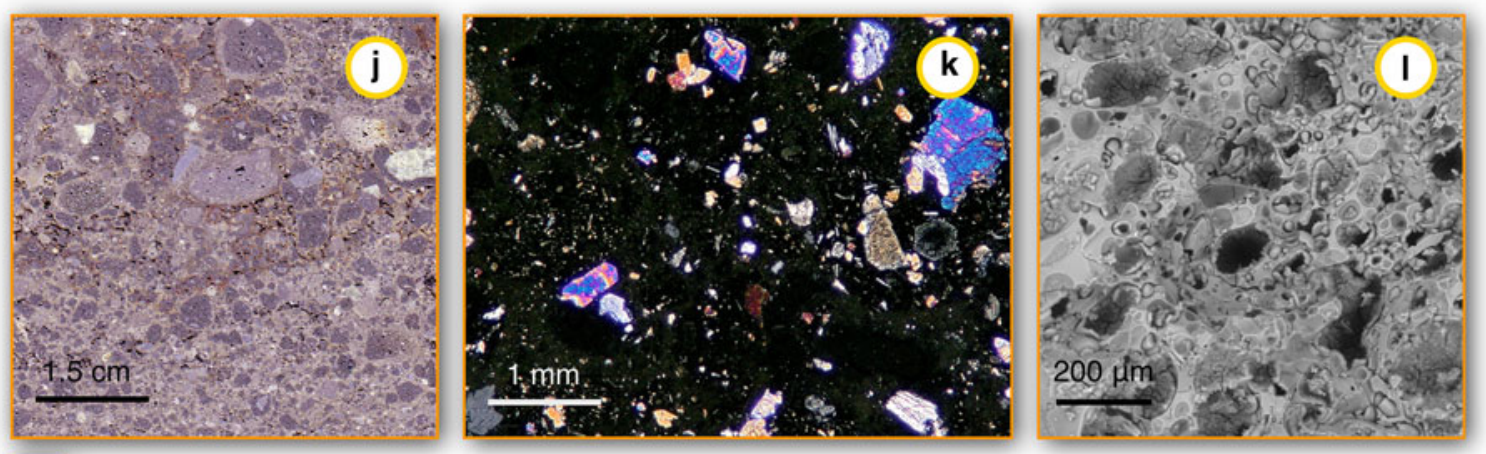

HW Habichtswald Tuff, Hesse / Germany

Fig. 4 Illustration of the volcanic rock samples described in detail. From top to bottom: Cantera Blanca Tuff, Tenayacátetl Tuff, Bufa Tuff and Habichtswald Tuff. (a, d, g, j) Polished section, (b, e, h, k) thin section under polarized light, (c, f, i, l) SEM micrograph 

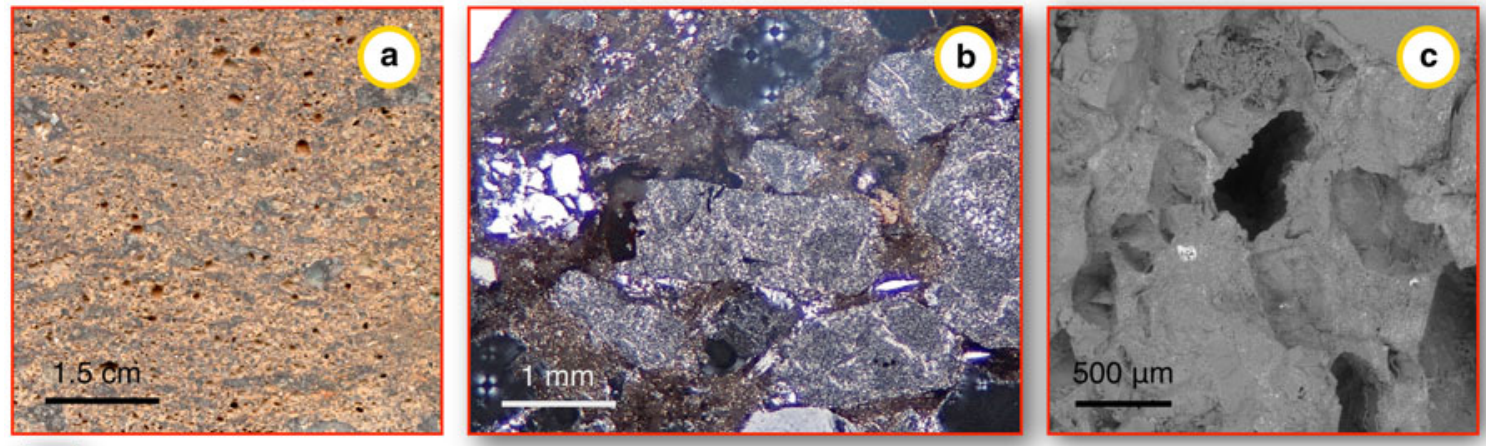

\section{RP Rochlitz Porphyr Tuff, Saxony / Germany}
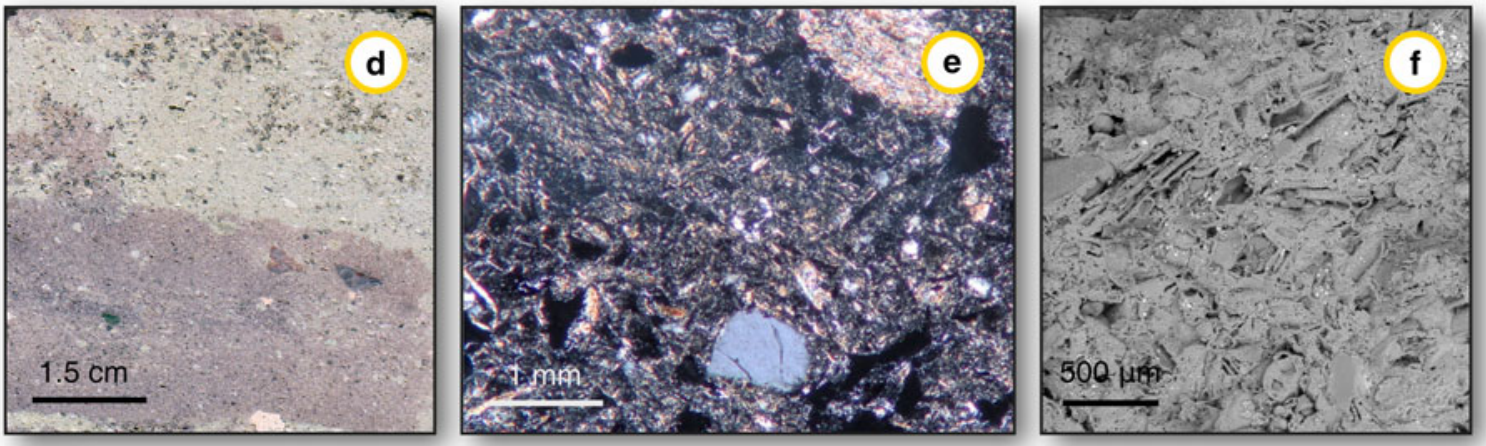

HD Hilbersdorf Tuff, Saxony / Germany
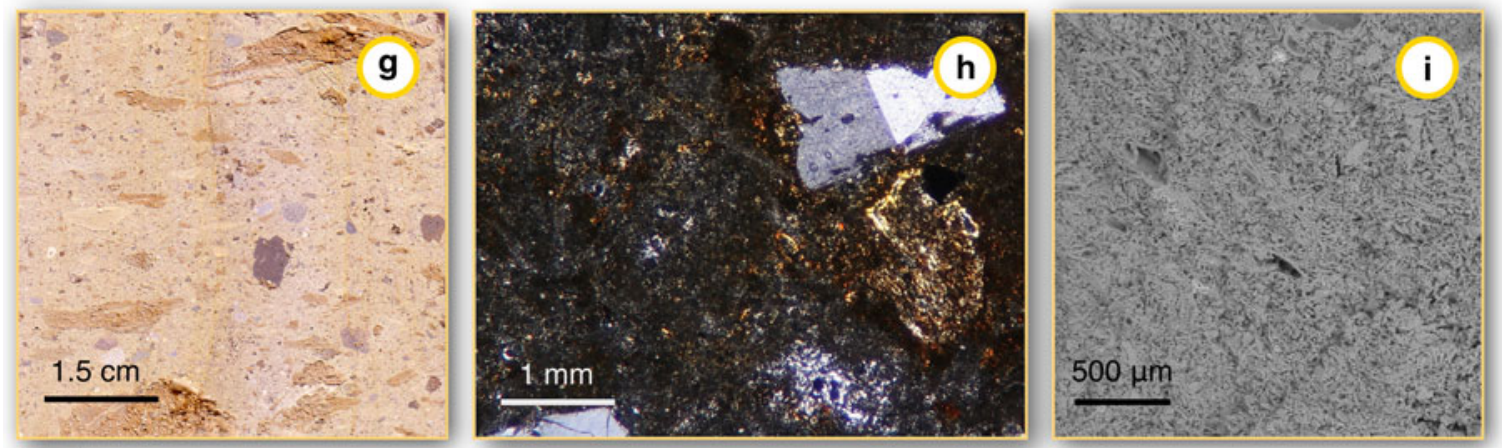

CA Cantera Amarilla Tuff, Jalisco / Mexico
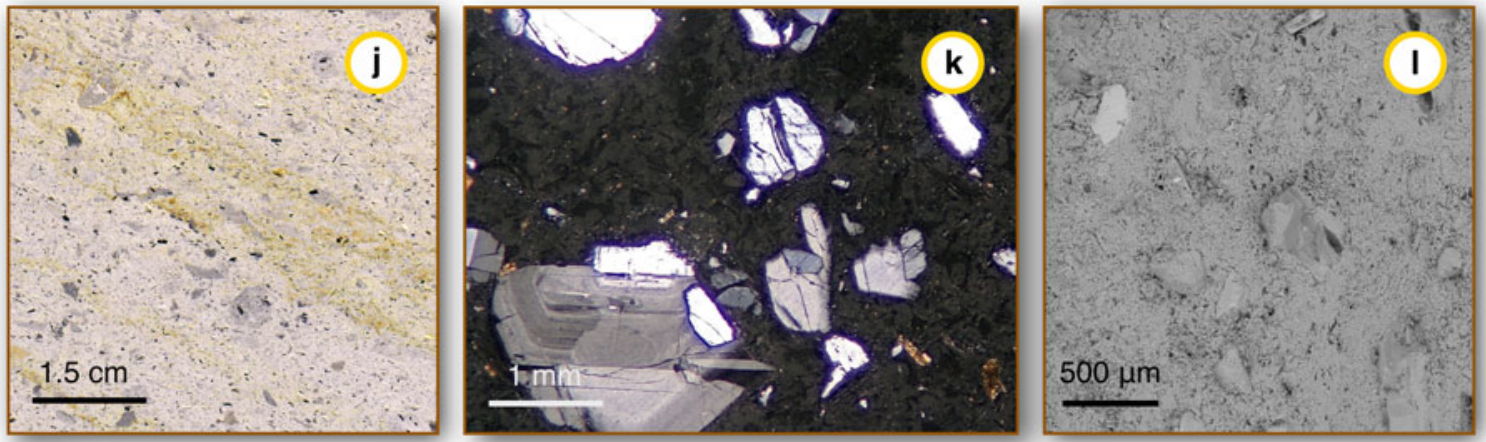

Eger-Demjén Tuff, Magyarország / Hungary

Fig. 5 Illustration of the volcanic rock samples described in detail. From top to bottom: Rochlitz Porphyr Tuff, Hilbersdorf Tuff, Cantera Amarilla Tuff and Eger-Demjén Tuff. (a, d, g, j) Polished section, (b, e, h, k) thin section under polarized light, (c, f, i, l) SEM micrograph 
Pore size distribution was measured by MIP (mercury intrusion porosimetry).

The capillary water absorption was measured with respect to the three principal directions ( $X, Y$ and $Z$ ) on sample cubes $65 \mathrm{~mm}$ in length. The cubes' bottom plane was placed into water to measure the weight increase over time.

The water vapour diffusion characterizes the diffusion resistance of a porous material compared to an equally dimensioned inactive air film and is one of the most important water transport mechanisms. The measuring method gives information about the network of the porous system, the drying behaviour and the transport mechanism controlled by the pore size distribution (Ruedrich and Siegesmund 2006). Slices of the different stones were prepared in all directions $(X, Y, Z)$ with a diameter of $4 \mathrm{~mm}$ and a thickness of $10 \mathrm{~mm}$ and were attached as covers on Teflon cups filled with water $(100 \% \mathrm{RH})$. These cups were then placed into a climate chamber at $50 \% \mathrm{RH}$ and a temperature of $20{ }^{\circ} \mathrm{C}$. The weight losses of the cups were measured every $24 \mathrm{~h}$ by calculating the moisture flow through the material.

Pressure will develop if the strain in the sample's dilatation is mechanically inhibited during water uptake (cf. Kocher 2005). Ruedrich et al. (2011) shows that, for sandstone, there is a clear correlation between moisture expansion and swelling pressure.

Swelling pressure was measured for five selected cylindrical samples with a diameter of $5 \mathrm{~cm}$ and a high of $2.5 \mathrm{~cm}$. Samples with a very high moisture dilatation (in this case the HD) were chosen, one with a high dilatation (LS), two samples with a medium dilatation (BT and $\mathrm{BP}$ ), and one with moderate expansions (CA). The samples were measured in the $Z$ direction while a preload $0.021 \mathrm{MPa}$ was given. Two techniques were used: a universal testing machine and a commercial odometer (Kocher 2005).

The splitting tensile strength (STS) was determined by means of the "Brazilian test", which involves disc-shaped specimens $40 \mathrm{~mm}$ in diameter and $20 \mathrm{~mm}$ in length. In order to calculate the average value, a minimum of six samples was used, while the normal amount was 10 samples. The splitting tensile strength was measured perpendicular to the $X Y$ and $X Z$ planes, where $X Y$ is the bedding plane. Tensile strength tests were conducted under dry and water-saturated conditions.

For the compressive strength measurements, tests were performed on standard specimens of $50 \mathrm{~mm}$ in diameter and $50 \mathrm{~mm}$ in length. The load was applied to the endfaces of the specimen with a strain rate of $1,000 \mathrm{~N} / \mathrm{mm}^{2} / \mathrm{s}$ until failure using a universal testing machine. The uniaxial compressive strength was measured under dry conditions.

\section{Petrography and mineralogy}

The tuff rock ages studied range from the Permian to the Recent, with chemical compositions that vary from basalt to dacite tuff up to rhyolitic ignimbrite tuff. For optical microscopy, the mineralogical composition of bulk samples and clay fractions were also analyzed using X-ray diffraction and cation-exchange capacity (CEC) determinations, respectively. The mineralogical composition, including clay minerals, is listed in Table 1.

Petrographical analyses of each tuff sample were performed on oriented thin sections under a polarisation microscope.

The Blanca Pachuca Tuff is a light grey to white pyroclastic rock with clearly acid composition (rhyolitic tuff). It is characterized by an almost total lack of macrocrystals and a fine, porcelain-like appearance (Fig. 4b). Only a few platy anhedral feldspar phenocrysts and some scarce idiomorphic quartz crystals were observed macroscopically. Little angular (anhedral) quartz crystals $(>0.2 \mathrm{~mm})$, sometimes grouped in fine laminaes, scattered biotite and hornblende crystals are also present. The tuff likewise shows a hydrothermal alteration causing epidotisation and argilitisation. The matrix is composed of glass together with significant amounts of smectites (montmorillonite) and zeolites (mordenite-clinoptilolite).

The Tenayocatetl Tuff is a greyish to red vulcanite with a characteristic porphyritic fabric (Wedekind et al. 2011). The tuff has a basic chemical composition and exemplifies a welded ash tuff with a small portion of lapilli fragments. The fine-grained, glassy matrix (around $60 \%$ of the rock) contains approximately $40 \%$ of clasts and crystals in grain sizes about $0.2-5 \mathrm{~mm}$. The matrix shows flow direction with intercalated light and dark-coloured bands and stripes (Fig. 4d). Altered crystals of plagioclase, hornblende, andesine, oligoclase, labradorite and augite are observable (Wedekind et al. 2011). The glassy matrix could be partly recrystallised as indicated by XRD. TY contains significant amounts of smectite (10-20\%).

The Bufa Tuff is a greyish, light pink/red to orange porphyritic rhyolitic tuff, which has around $10 \%$ quartz and sanidine phenocrysts, together with isolated, wellflattened pumice. More important in this tuff are the angular to subangular, abundant lithic components (15-20\% of the rock), which can be up to $15 \mathrm{~cm}$ in diameter. The lithic fragments are basically red to dark red coloured. Subhedral to euhedral quartz, plagioclase, biotite flakes and dispersed pyroxenes and olivine crystals are present in a microcrystalline and partially devitrified glassy matrix (Fig. 4h). The fine-grained matrix is composed of calcite, hematite (principal cause of the pinkish, reddish colour) and small amounts of illite plus illite-smectite mixed layer of different ordering types. 
Table 1 semi-quantitative analyses of clay minerals and the CEC-value of the chosen samples

\begin{tabular}{|c|c|c|c|c|c|c|c|c|c|c|c|c|}
\hline Sample & Smectite & Chlorite & $\begin{array}{l}\text { K-S } \\
\text { (R0) }\end{array}$ & $\begin{array}{l}\mathrm{I}-\mathrm{S} \\
\text { (R0) }\end{array}$ & $\begin{array}{l}\text { I-S } \\
\text { (R3) }\end{array}$ & $\begin{array}{l}\text { Muscovite/ } \\
\text { illite }\end{array}$ & $\begin{array}{l}\text { Biotite/ } \\
\text { phlogopite }\end{array}$ & Kaolinite & Halloysite & Quartz & $\begin{array}{l}\text { Cristobalite/ } \\
\text { tridymite }\end{array}$ & Glass \\
\hline $\mathbf{B P}$ & $\mathrm{XX}$ & & & & & & + & & & $\mathrm{XX}$ & & \\
\hline TY & $\mathrm{XX}$ & & & & & & & & & & $\mathrm{XX}$ & \\
\hline BT & & & & $\mathrm{X}$ & $\mathrm{X}$ & $\mathrm{X}$ & + & & & XXX & & \\
\hline CA & $\mathrm{x}$ & & & & & & & $\mathrm{x}$ & $\mathrm{x}$ & & $\mathrm{X}$ & \\
\hline HW & $\mathrm{XX}$ & & & & & & & & & $\mathrm{X}$ & & $\mathrm{XX}$ \\
\hline HD & & & & & $\mathrm{XX}$ & $\mathrm{XX}$ & & & & XXX & & \\
\hline $\mathbf{R P}$ & & & & & & & + & & & XXX & & \\
\hline ED & $\mathrm{X}$ & & & & & & $X$ & & & $\mathrm{x}$ & & $\mathrm{XXX}$ \\
\hline Sample & Calcite & K-feldspar & Plagi & clase & Hornblen & ide Analcime & Clino-ptilolite & e Diopside & le Augite & Olivine & Hematite & Meq/100 g \\
\hline $\mathbf{B P}$ & & $\mathrm{XX}$ & $\mathrm{X}$ & & + & & $\mathrm{XX}$ & & & & & 15.6 \\
\hline TY & & $\mathrm{XX}$ & $\mathrm{XXX}$ & & $\mathrm{x}$ & & & & + & & $\mathrm{x}$ & 17.6 \\
\hline BT & $\mathrm{x}$ & $\mathrm{X}$ & $\mathrm{XXX}$ & & & & & & + & + & + & 3.0 \\
\hline CA & & $\mathrm{XXX}$ & $\mathrm{XXX}$ & & & & & & & & & 4.2 \\
\hline HW & & $\mathrm{XX}$ & + & & & & & $X X$ & & $\mathrm{XX}$ & & 16.8 \\
\hline HD & & $\mathrm{XXX}$ & & & & & & & & & & 0.7 \\
\hline $\mathbf{R P}$ & & & & & & & & & & & + & 1.1 \\
\hline ED & & XX & $X X$ & & $\mathrm{x}$ & & & & & & & 10.4 \\
\hline
\end{tabular}

Semi-quantitative: + traces, $\mathrm{x}$ minor component, X 5-10\%, XX 10-20\%, XXX > $20 \%$

The Cantera Amarilla Tuff is a yellowish to orangebrownish porphyritic tuff (hypercrystalline to aphanitic texture) with clasts of very different sizes. The clasts are mainly poor flattened light brown to brownish-reddish pumice and other lithoclasts (basalts and other volcanic fragments), which can have diameters of a few $\mathrm{mm}$ (sand grain size) up to $10 \mathrm{~cm}$ and sometimes more (Fig. $5 \mathrm{~g}, \mathrm{i}$ ). The crystals are practically only platy and tabular, sub to euhedral, well-twinned alkali feldspar phenocrysts, and seldom-rounded reworked quartz and unidentified opaque crystals. The Cantera Amarilla Tuff is rich in K-feldspar and plagioclase; quartz is absent but cristobalite, tridymite, and clay minerals are accompanying minerals. Smectite, kaolinite and halloysite were identified in separated clay fractions.

The Habichtswald Tuff shows a wide spectrum in grain sizes of the fragments, ranging from several millimetres up to $5 \mathrm{~cm}$. Its characteristic dark greyish, glassy to microcrystalline groundmass contains a great amount of montmorillonite. This tuff has a hypocrystalline texture with euhedral olivine-pyroxene crystals, while plagioclase, amphibole and biotite are also recognizable (Fig. 4k). Clasts of pre-existing basic rocks are also present as vitreous fragments (peridotite and basaltic clasts; Stueck et al. 2008).

The Hilbersdorf Tuff shows different varieties in grain size and colour. It can be pale pink to brick red, light or dark purple or greenish, and often shows a peculiar alteration with light pink or greenish speckles, spots or strips (Fig. 5d). In the fine-grained matrix of the tuff (around $60-70 \%$ of the rock), lapilli inclusions were observed; however, the average grain size varied from 0.5 to (rarely) coarser than $2 \mathrm{~mm}$. Larger cavities from several $\mathrm{mm}$ to $\mathrm{cm}$, mostly amygdaloyd-type, were partially filled with clay minerals. It consists of mono- and polycrystalline quartz, alkali feldspar and seldom of lithic grains of metamorphic rocks (sericite-rich), quartzite and gneiss-like xenoliths in a hypocrystalline to eutaxitic texture (Fig. 5e). In addition to quartz and feldspar, XRD proved the presence of approximately 20 wt $\%$ muscovite/illite. SEM (scanning electron microscope) images of the matrix of the Hilbersdorf Tuff (Fig. 5f), additionally demonstrated the presence of dickite, a clay mineral that belongs to the kaolinite-group.

The Rochlitz porphyry has a red rhyolitic groundmass composed of quartz, feldspars, thin biotite crystals and elongated, flattered porous glass fragments in different grades. The fine-grained to glassy, sometimes granular and well-porous reddish to dark red-brownish matrix exhibits a moderate flow fabric (Fig. 5b). The pore space is mostly filled kaolinite (around $50 \%$ ). Within the matrix (40-70\%), up to $4 \mathrm{~mm}$ rounded to euhedral quartz crystals and 1-3 mm white, tabular to columnar relictic alkali feldspars (completely replaced by clay minerals) occur as phenocrysts. The reddish colour of the tuff is caused by hematite present in the matrix. 
The Eger-Demjén Tuff is a greyish to light brownish ignimbrite, which has clasts of very different sizes. The clasts, measuring between 1 and $30 \mathrm{~mm}$, are mainly elongated, flattened pumice fragments, in addition to which large plagioclase and hornblende phenocrysts can be recognized (Fig. 5k). Microcrystalline porphyritic fabric in a eutaxitic to glassy texture with flattened well-welded vitroclast can also be observed. The main constituents are euhedral to subhedral plagioclase crystals, which show a very impressive zonal texture, together with plagioclase, subhedral quartz, corroded hornblende and altered biotite (partially altered to chlorite; Stueck et al. 2008). Smectite occurs in relatively large amounts, approximately $10 \mathrm{wt} \%$.

The Weibern Tuff is a yellowish to light brown phonolitic volcanic rock that consists principally of $85 \%$ matrix and $15 \%$ clasts. The matrix is rich in analcime, muscovite/ illite, quartz and calcite. The clasts include rock fragments, euhedral to anhedral crystals and pumice, and its grain sizes range from 0.5 up to $10 \mathrm{~mm}$. The thin section shows that the rock fragments are sandstones, shales and basalts and other unidentified volcanic glass fragments. The crystals are predominantly reworked quartz from sedimentary rocks, olivine, pyroxenes and feldspars. Flattened pumice occurs likewise embedded in the porphyritichyalopilitic groundmass.

The Gris de los Remedios Tuff was described as a lapilli tuff with an andesitic chemical composition (Wedekind et al. 2011). The colour of this well-welded tuff is grey to light grey. The matrix contain phenocrysts of up to $10 \mathrm{~mm}$ large prismatic hornblende and other, smaller melanocratic minerals (dark), idiomorphic plagioclase crystals and large lithic fragments (light), mainly pumice. The texture of this tuff is clearly hypocrystalline. The bulk sample also contains significant amounts of cristobalite, K-feldspar, smectites and traces of muscovite/illite and quartz.

The Chiluca Tuff is a compact andesitic, porphyritic tuff with a hypocrystalline texture. The tuff is grey in colour with dark and light inclusions of mafic and felsic minerals. The rock does not show a visible orientation of the crystals, nor are flow textures present. In the thin section, euhedral and subhedral well-zoned and twined plagioclase, idiomorphic amphibole (hornblende) and large tabular biotite are observed. Pyroxene and olivine are scarce. The clay fractions show illite and an illite-smectite mixed layer mineral, however, the amounts are small.

The Loseros Tuff is a felsic volcanoclastic rock with rhyolitic composition that consists of very well sorted, fineto-medium, sand-sized crystals and detrital rock fragments, which are embedded in an ash-rich and strong, altered groundmass. The Loseros Tuff can appear in different colour tones like greenish, reddish, purple and greyish, but the greenish variety is characteristic and most frequently used in construction (Buchanan 1980; López-Doncel et al.
2012). The majority of the grains are quartz, plagioclase and volcanic lithic fragments (Edwards 1956). The crystals are angular to subhedral plagioclase, angular quartz, and strong altered biotite flakes. In thin section, it is possible to recognize a microlamination (laminae), due to the variations in the frequency of the sand-sized fragments and the matrix. The Loseros Tuff comes in different varieties. The difference is related to the grain size and lime content. Within the matrix, between $5 \%$ to more than $20 \%$ calcite can be found. The matrix also contains kaolinite; however, dioctahedral clay minerals illite plus R3 ordered illite (0.95)-smectite mixed layers are the most common.

The Cantera Rosa Tuff is a pinkish to reddish rhyolitedacite tuff (rhyodacite). CR is an attractive building stone because of the fine and homogenous groundmass contrast with the presence of centimetre to decimetre sized, more or less altered pumice clasts. It is likely that the presence of olivine and a little bit of biotite give the tuff its characteristic pinkish-reddish colour. The clasts are characteristic because their matrix is normally a darker reddish colour. The clasts occur in different sizes and shapes, from angular and flattened to sub-rounded, but they are primarily oriented in the flow direction. When the pumice clasts are altered and eroded, the tuff looks porous. The fine hypocrystalline groundmass (completely opaque) consists of quartz and feldspar, which are intercalated with little glass shards (vitroclasts). The XRD pattern shows a feldspar-rich matrix with anorthite, orthoclase, sanidine, and in lesser amounts, quartz and traces of cristobalite. The clay fraction contains smectite and also rarely found R0 ordered kaolinite (0.85)-smectite mixed layer minerals.

The Cantera Formación Tuff is a pinkish to reddish, massive rhyolitic ignimbrite tuff (hypocrystalline and partially eutaxitic, porphyritic texture), with plenty of noncollapsed pumice at an average size of $2 \mathrm{~cm}$, with 15-20\% of quartz, sanidine and less abundant biotite. The main components are euhedral sanidine (40\%), anhedral to euhedral quartz (40\%), weakly zoned oligoclase (4\%), biotite and magnetite usually altered to hematite (1\%). The matrix (75-80\% of the rock), shows vitroclastic texture in outlying areas to the phenocrysts and near them is good eutaxitic foliation. In general, the matrix displays a weak birefringence, suggesting that it devitrified to a felsitic cryptocrystalline aggregate. XRD analysis indicates, that this tuff is poor in clay minerals, only containing illite and poorly ordered 1:1 clay minerals (kaolinite and halloysite were proven by IR, infrared spectroscopy).

\section{Petrophysical properties}

All the measurements were done in all three dimensions of the different rocks. The direction parallel to the bedding 


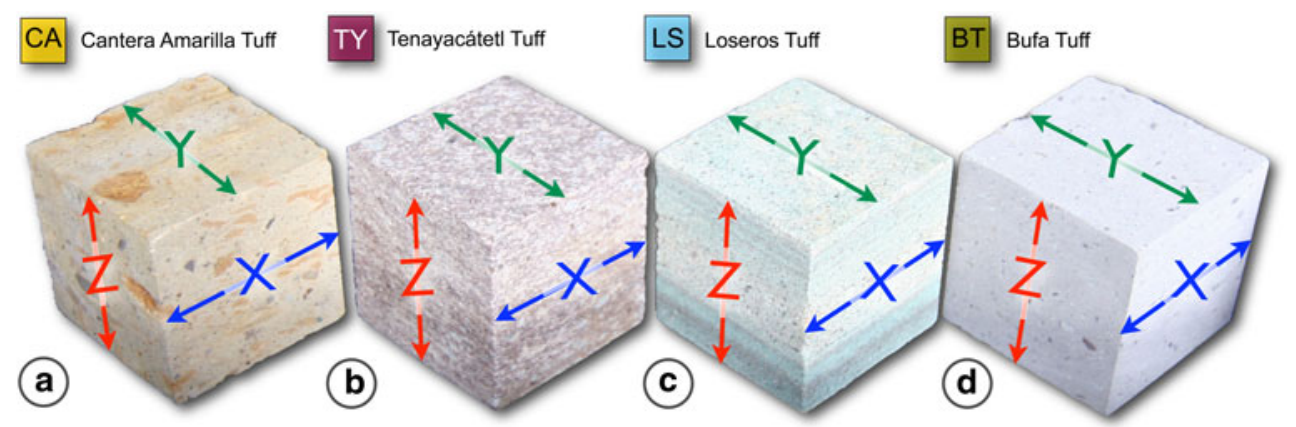

Fig. 6 Four samples illustrated as examples for the general texture of the investigated rocks and their division into different directions: a clastic material, like brownish pumice inclusions, is found oriented parallel to a possible flow direction of the Cantera Amarilla Tuff. The direction with an elongated accumulation of clasts is defined as the $X$ direction. The adjustment of the clasts in a more or less horizontal position describes the bedding of the tuff. The direction perpendicular to the bedding is defined as the $Z$ direction. b Long extended aggregates of different minerals describe the flow direction of the TY tuff ( $X$ direction). c The fine lamination of the Loseros Tuff also describes the bedding structure of the material. d Extended, darkcoloured, iron-rich minerals show a lenticular shape and are defined as the $X$ direction. The direction perpendicular to these minerals is defined as the $Z$ direction

Table 2 Pore space properties, moisture transport, and retention properties of the different tuffs

\begin{tabular}{|c|c|c|c|c|c|c|c|c|c|c|c|c|c|c|}
\hline Stone type & WB & ED & HW & $\mathrm{RP}$ & HD & $\mathrm{BT}$ & LS & $\mathrm{CR}$ & $\mathrm{CA}$ & TY & $\mathrm{CH}$ & GR & $\mathrm{BP}$ & $\mathrm{CF}$ \\
\hline Effective porosity (vol\%) & 37.1 & 24.56 & 8.76 & 27.13 & 30.24 & 18.39 & 7.06 & 40.8 & 41.56 & 4.74 & 7.95 & 31.03 & 15.26 & 12.83 \\
\hline Particle density $\left(\mathrm{g} \mathrm{cm}^{-3}\right)$ & 2.43 & 2.29 & 2.59 & 2.64 & 2.63 & 2.61 & 2.34 & 2.56 & 2.53 & 2.38 & 2.58 & 2.55 & 2.53 & 2.6 \\
\hline Bulk density $\left(\mathrm{g} \mathrm{cm}^{-3}\right)$ & 1.52 & 1.48 & 2.38 & 1.92 & 1.83 & 2.13 & 2.18 & 1.53 & 1.48 & 2.26 & 2.37 & 1.82 & 1.84 & 2.26 \\
\hline Average pore radius $(\mu \mathrm{m})$ & 0.412 & 0.495 & 0.004 & 0.335 & 0.145 & 0.06 & 0.095 & 0.988 & 0.554 & 0.303 & 0.358 & 1.285 & 0.035 & 0.804 \\
\hline Micropore porosity (\%) & 16 & 14 & 70 & 21 & 51 & 82 & 95 & 13 & 18 & 47 & 27 & 15 & 97 & 15 \\
\hline \multicolumn{15}{|l|}{$w$ value $\left(\mathrm{kg} / \mathrm{m}^{2} \sqrt{\mathrm{h}}\right)$} \\
\hline$X$ & $16.01^{\mathrm{a}}$ & 0.291 & $3.1^{\mathrm{a}}$ & $4.8^{\mathrm{a}}$ & 0.163 & 0.18 & 0.026 & 6.86 & 3.34 & 0.11 & 0.39 & 8.30 & 0.147 & 0.113 \\
\hline$Y$ & - & 0.355 & - & - & 0.197 & 0.21 & 0.048 & 6.78 & 3.78 & 9.16 & 0.34 & 9.08 & 0.134 & 0.110 \\
\hline$Z$ & $15.77^{\mathrm{a}}$ & 0.226 & $2.82^{\mathrm{a}}$ & $4.6^{\mathrm{a}}$ & 0.175 & 0.17 & 0.045 & 6.43 & 0.51 & 0.1 & 0.38 & 6.21 & 0.073 & 0.066 \\
\hline Average $\varnothing$ & 15.89 & 0.290 & 2.96 & 4.7 & 0.178 & 0.186 & 0.039 & 6.69 & 2.54 & 3.12 & 0.37 & 7.86 & 0.118 & 0.096 \\
\hline Anisotr & 1.5 & 36 & 9 & 4 & 17 & 16 & 46 & 32 & 87 & 99 & 13 & 13 & 50 & 42 \\
\hline \multicolumn{15}{|l|}{$\mu$ value } \\
\hline$X$ & 9.25 & 19,45 & 22.33 & 12.88 & 13.83 & 16.7 & 64.5 & 9.89 & 7.27 & 22.27 & 88.97 & 10.04 & 15.37 & 78.28 \\
\hline$Y$ & 9.38 & 12.38 & 20.42 & 12.44 & 12.88 & 14.08 & 40.93 & 10.2 & 7.58 & 36.43 & 59.86 & 9.75 & 16.51 & 70.61 \\
\hline$Z$ & 9.39 & 24.42 & 24.02 & 15.47 & 17.30 & 19.28 & 66.7 & 10.35 & 7.72 & 80.51 & 118.56 & 10.35 & 21.52 & 130.27 \\
\hline Average $\varnothing$ & 9.34 & 18.75 & 22.25 & 13.59 & 14.67 & 16.68 & 57.37 & 10.14 & 7.52 & 46.40 & 89.13 & 10.04 & 17.8 & 93.05 \\
\hline Anisotropy (\%) & 1.5 & 49 & 15 & 19.5 & 25.5 & 15.5 & 39 & 4 & 6 & 72 & 49.5 & 6 & 27 & 46 \\
\hline $\begin{array}{l}\text { Sorption } 95 \% \text { rh } \\
\left(\mathrm{g} / \mathrm{cm}^{3}\right)\end{array}$ & 0.043 & 0.067 & 0.120 & 0.026 & 0.045 & 0.054 & 0.090 & 0.0085 & 0.039 & 0.066 & 0.0084 & 0.047 & 0.130 & 0.0061 \\
\hline
\end{tabular}

${ }^{a}$ Stueck (2006)

and lamination is defined as $X$, the direction perpendicular to the lamination as $Y$ and the direction perpendicular to the bedding as $Z$ (compare also Fig. 6).

\section{Porosity}

Four different groups can be distinguished according to their effective porosity. Group 1: porosities ranging from 0 to 10 vol\%; Group 2: from 10 to 20 vol\%; Group 3: from
20 to 30 vol\%; and Group 4 with porosities between 30 to more than 40 vol\% (Table 2).

Within group 1, TY with $4.7 \mathrm{vol} \%$ and HW with 8.8 vol\% have the lowest and highest, effective porosity, respectively. The other tuffs of this group (LS and $\mathrm{CH}$ ) range between 7 and 8 vol\% (Table 2).

Within group 2, three tuffs show porosities ranging between 12.8 and 18.4 vol\% (CF, BP, BT, see Table 2). Only two tuffs (ED, RP) have a porosity between 25 and up to $27 \mathrm{vol} \%$ (Table 2). The last group comprises four tuffs 
with a porosity ranging between 30 and up to 42 vol\% (HD, WB, CR, and CA).

\section{Density}

Bulk density ranges between 1.38 and $2.38 \mathrm{~g} / \mathrm{cm}^{3}$ (Table 2). Only two samples have a low bulk density between 1.38 and 1.48 (ED, CA). Five samples range between 1.52 and $1.92 \mathrm{~g} / \mathrm{cm}^{3}$ (WB, CR, GR, HD, and RP). The other six have a density from 2.13 up to $2.38 \mathrm{~g} / \mathrm{cm}^{3}$ (BT, LS, TY, CF, CH, and HW).

\section{Microporosity}

The tuff rocks investigated have a low (up to $50 \%$ ) or a high amount (up to $100 \%$ ) of micropores measured by mercury porosity (Fig. 7). The microporosity is defined as the pores between 0 and $0.01 \mu \mathrm{m}$, the capillary active pores range between 0.01 and $10 \mu \mathrm{m}$ after Klopfer (1985). After Klopfer three clear regions can be differentiated depending on water transport and other mechanism involved. For microprobes pore diameters $<0.1 \mu \mathrm{m}$ water will condense at relative humidity values below
$99 \%$ RH. In pores between $1 \mu \mathrm{m}$ and $1 \mathrm{~mm}$ capillary suction takes place (Siegesmund and Duerrast 2011). The microporosity of the investigated rocks ranges between 13 and $97 \%$. All results are listed in Table 2 and illustrated in Fig. 7.

As pertains to the eight rock types explained in detail, BP has the highest microporosity with $97 \%$, followed by BT with $82 \%$, HW with $70 \%$ and HD with $51 \%$. The tuffs with a low microporosity are ED with $14 \%$, CA with $18 \%$, RP with $21 \%$ and TY with $47 \%$ (Fig. 6).

\section{Pore radii distributions}

Pore size distribution measured by mercury porosimetry can be put into groups of ideal pore size types like unimodal equal and unequal, and bimodal unequal (Siegesmund and Duerrast 2011). The investigated tuffs show diverse pore types including transitional ones.

The group with largely equal porous structure and a limited spectrum of pore sizes consists of BT and BP (Figs. 7, 8). Both nearly only have microporosity (0.01-0.1 $\mu \mathrm{m}$ pore size) with 78 and $90 \%$, respectively.

Their pore size distributions proceed in a uniform pattern with a low tendency to an unequal unimodal structure
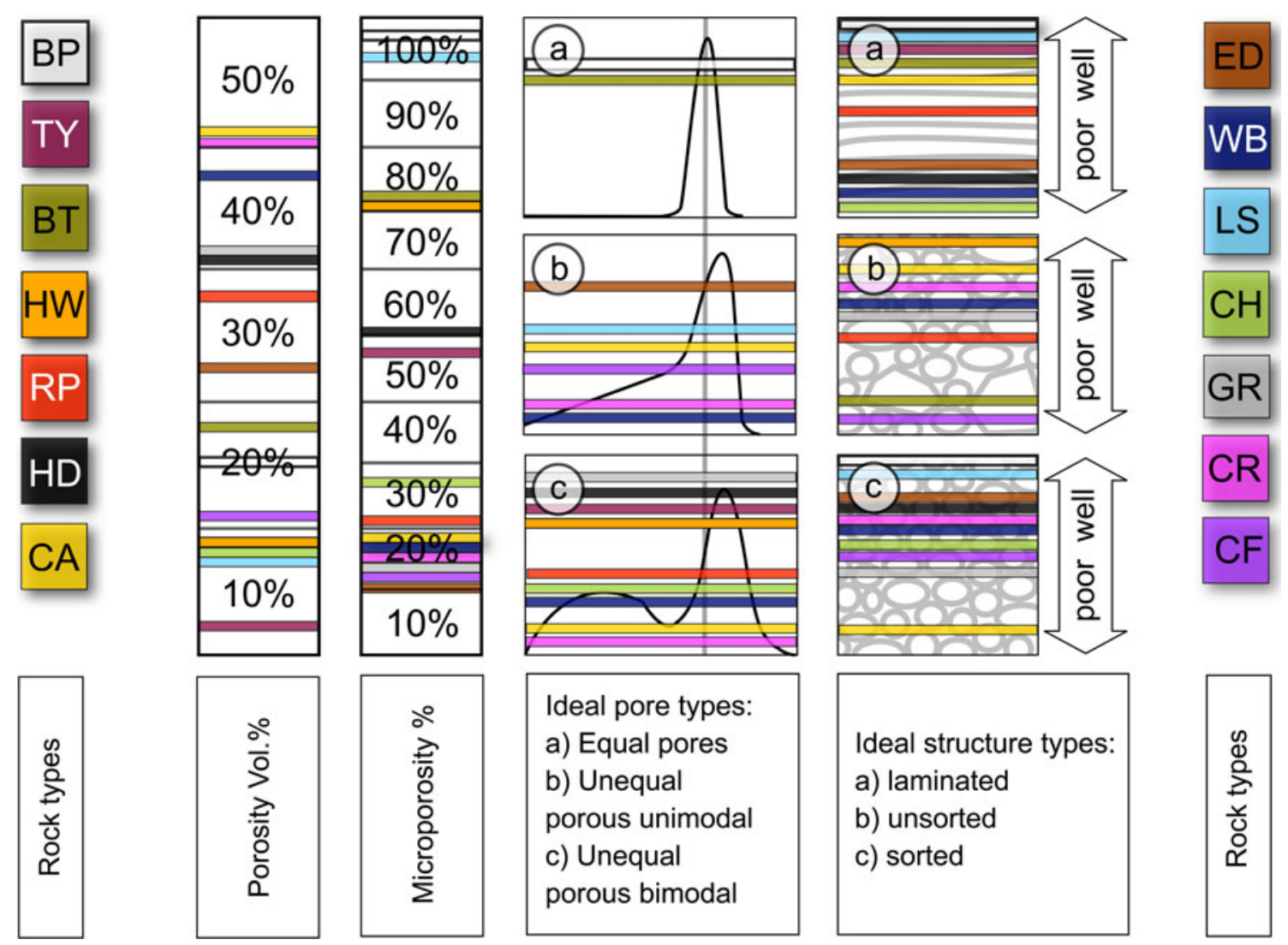

Fig. 7 Overview diagram of the main pore space properties and structural characteristics measured by hydrostatic weighting and MIP 

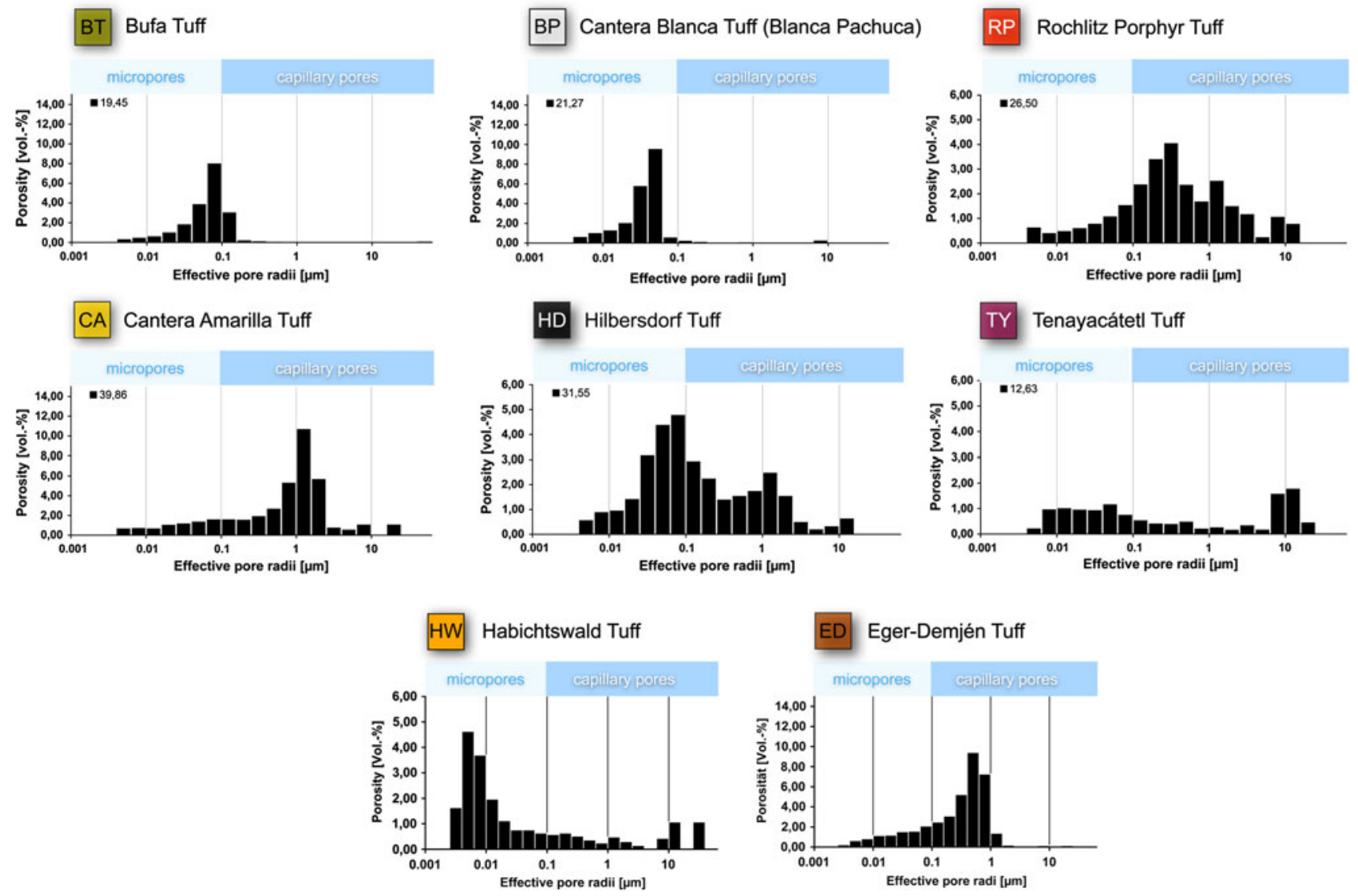

Fig. 8 Pore size distribution of the eight investigated tuffs described in detail, measured by hydrostatic and MIP

(Figs. 7, 8). Both tuffs also are comparable in porosity and density (Table 2).

Both RP and LS belong to the group of equal pore size types with a wider spectrum of pore sizes. $52 \%$ of the pores in RP are between 0.1 and $1 \mu \mathrm{m}$, but in general, both tuffs have pores between 0.0015 and $10.1 \mu \mathrm{m}$. This group is represented by RP, shown in Fig. 8.

The group of unequal pore size types with a unimodal spectrum of pore sizes consists of $\mathrm{CA}, \mathrm{CF}, \mathrm{CR}, \mathrm{WB}$, and ED. This group is represented by CA and ED (Fig. 8).

The tuffs with a large amount of capillary active pores $(1-10 \mu \mathrm{m})$ are CA with $82 \%$ and CR with $87 \%$. Consequently, the micropores range between 13 and $18 \%$ (Table 2).

Eight of the tuffs investigated show an unequal pore size type with a bimodal spectrum of pore sizes (Fig. 7). Three tuffs have a poorly developed bimodal spectrum and the two remaining tuffs only show a low tendency to a bimodal pattern. The majority of the eight selected tuffs have a higher amount of capillary pores than micropores and only two of them (HW and HD) contain more micropores than capillary pores.

TY and HD have practically the same amount of capillary and micropores (around $47 \%$ ). The Habichtswald Tuff mostly has micropores ( $72 \%$ ), but also contains some large capillary active pores and even macropores. RP has a ratio of 1:2 between micropores and capillary active pores, with a low tendency to a bimodal pore size spectrum. CA, with $83 \%$, has the highest amount of capillary active pores of the selected tuffs $(83 \%)$ and has also some macropores.

\section{Macroscopic/textural aspects}

The arrangement and the spatial distribution of the components into a tuff (matrix and fragments) seem to play an important role in the behaviour of their petrophysical, mechanical and moisture properties. Moreover, some tuffs have no remarkable array components and appear to have no major differences between fragments and matrix, giving them a rather homogeneous and massive appearance, while most samples exhibit an orientation of the clasts with lamination or layering. Of the 14 rocks investigated, six show well-developed layering (BP, TY, HW, BT, CA, and RP, Figs. 4, 5). On the other hand, six tuffs show marked differences between the size, shape and amount of the fragments and their contents in matrix, giving them a very inhomogeneous (unsorted) appearance (Fig. 7). ED and the HD show an almost homogenous, well-sorted structure. 
Fig. 9 Hydric expansion under water-saturated conditions of the different tuff samples

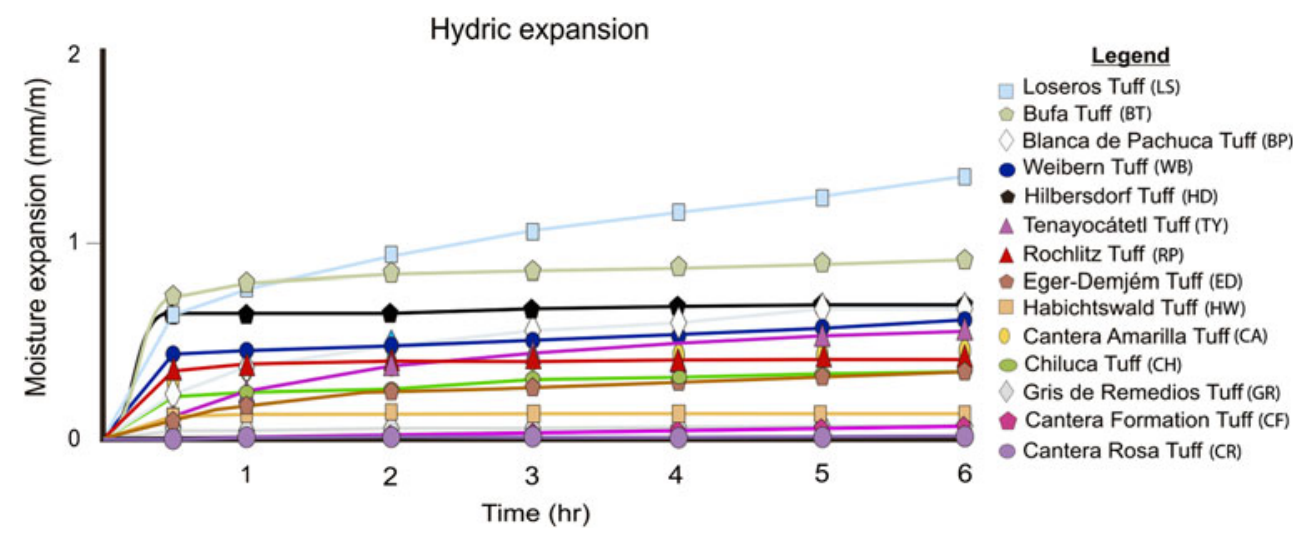

Our observations allow us to suggest that the spatial distribution of the different fragments, like their layering, and their proportion with respect to the matrix seem to have a significant effect on moisture uptake, sorption, and mechanical properties, and are determinant for the moisture expansion often associated with a clear anisotropy.

\section{Moisture expansion}

The hydric expansion shows values that range from $1.4 \mathrm{~mm} / \mathrm{m}$ for LS up to near moisture contraction for CR and CF (Fig. 9).

There are notable differences in the values of the expansion under water-saturated conditions. The LS showed the largest hydric expansion with $1.4 \mathrm{~mm} / \mathrm{m}, \mathrm{CR}$ even a reduction in length with $-0.03 \mathrm{~mm} / \mathrm{m}$ (Fig. 8). Some horizons of HD (not included in this study) can show a hydric expansion of up to $6 \mathrm{~mm} / \mathrm{m}$. In general, the expansion perpendicular to the layering is the largest.
Six tuffs have a moisture expansion between 0.5 and $1 \mathrm{~mm} / \mathrm{m}$ and another seven samples showed values ranging from $0.4 \mathrm{~mm} / \mathrm{m}$ to above zero (Table 3 ).

Apart from LS, CA shows the highest values of hydric dilatation perpendicular to the lamination ( $Z$ axis) with $0.9 \mathrm{~mm} / \mathrm{m}$ and an anisotropy of $82 \%$, followed by BT with $0.8 \mathrm{~mm} / \mathrm{m}$ and $55 \%$ anisotropy, and $0.6 \mathrm{~mm} / \mathrm{m}$ for $\mathrm{HD}$ and BP, with anisotropy values of 24 and $8 \%$, respectively (Table 3). TY has a moisture expansion of $0.5 \mathrm{~mm} / \mathrm{m}$ and a high anisotropy of $71 \%$, while the RP reached a hydric dilatation of $0.42 \mathrm{~mm} / \mathrm{m}$ with a low anisotropy of $8.1 \%$.

HW and ED both show a moderate hygric and hydric dilatation and a high similar anisotropy between 50 and $60 \%$.

\section{Capillary water absorption}

The calculated water absorption coefficient ( $w$ value) is given in Table 2 for all directions. The average $w$ value of

Table 3 Hygric expansion in mm depending on relative humidity and water saturation, the difference in percent for the three directions $(X, Y$, $Z$ ) and its anisotropy

\begin{tabular}{lllllllllllllll}
\hline Stone type & WB & ED & HW & RP & HD & BT & LS & CR & CA & TY & CH & GR & BP & CF \\
\hline$X$ 95 \% RH & 0.57 & 0.11 & 0.34 & 0.02 & - & 0.18 & 0.14 & 0.29 & 0.18 & 0.27 & 0.08 & 0.39 & 0.6 & - \\
$X$ wet & 0.241 & 0.145 & 0.248 & 0.360 & 0.467 & 0.361 & 0.314 & 0.0006 & 0.12 & 0.17 & 0.286 & 0.022 & 0.45 & -0.051 \\
$X$ diff. (\%) & 58 & 24 & 27 & 94 & - & 50 & 55 & 99.8 & 33 & 63 & 72 & 94 & 25 & - \\
$Y$ 95 \% RH & 0.48 & - & 0.29 & 0.01 & - & 0.203 & 0.254 & 0.28 & 0.16 & 0.28 & 0.08 & 0.42 & 0.73 & - \\
$Y$ wet & 0.351 & 0.201 & 0.295 & 0.379 & 0.578 & 0.442 & 0.555 & 0.0003 & 0.11 & 0.27 & 0.283 & 0.021 & 0.56 & -0.01 \\
$Y$ diff. (\%) & 27 & - & 15 & 97 & - & 54 & 54 & 99.9 & 31 & 4 & 72 & 95 & 23 & - \\
$Z$ 95 \% RH & 0.65 & 0.19 & 0.29 & 0.02 & - & 0.33 & 0.33 & -0.001 & 0.17 & 0.44 & 0.09 & 0.32 & 0.65 & \\
$Z$ wet & 0.585 & 0.353 & 0.235 & 0.427 & 0.618 & 0.798 & 1.428 & 0.0012 & 0.90 & 0.54 & 0.302 & 0.031 & 0.55 & -0.026 \\
$Z$ diff (\%) & 10 & 46 & 19 & 95 & - & 59 & 77 & & 81 & 19 & 70 & 90 & 15 & - \\
Anisotropy 95 \% (\%) & 26 & 42 & 15 & 50 & - & 45 & 75 & 71 & 11.1 & 39 & 11.1 & 24 & 18 & - \\
Anisotropy wet (\%) & 49.3 & 59 & 49.3 & 8.1 & 24.4 & 54.7 & 78 & 32.7 & 82 & 71.4 & 5.2 & 32.2 & 8.1 & 65 \\
Average 95 \% & 0.56 & 0.15 & 0.30 & 0.016 & - & 0.24 & 0.24 & 0.19 & 0.17 & 0.33 & 0.083 & 0.38 & 0.66 & - \\
Average wet & 0.40 & 0.23 & 0.26 & 0.366 & 0.55 & 0.53 & 0.78 & 0.0007 & 0.38 & 0.33 & 0.29 & 0.025 & 0.52 & -0.029 \\
\hline
\end{tabular}


the volcanites varies between almost $16 \mathrm{~kg} / \mathrm{m}^{2} \sqrt{\mathrm{h}}$ for WB and $0.04 \mathrm{~kg} / \mathrm{m}^{2} \sqrt{\mathrm{h}}$ for LS. Four groups can be divided according to their water absorption coefficients. Group 1 from $>0$ to $0.2 \mathrm{~kg} / \mathrm{m}^{2} \sqrt{\mathrm{h}}$, group 2 from $<0.2$ to 1.0 $\mathrm{kg} / \mathrm{m}^{2} \sqrt{\mathrm{h}}$, group 3 from $<1.0$ to $>10 \mathrm{~kg} / \mathrm{m}^{2} \sqrt{\mathrm{h}}$ and group 4 from $<10 \mathrm{~kg} / \mathrm{m}^{2} \sqrt{ } \mathrm{h}$. Group 1, with the lowest water uptake rate, consists of five tuffs ranging from LS to 0.19 $\mathrm{kg} / \mathrm{m}^{2} \sqrt{\mathrm{h}}$ for BT with an anisotropy from 16 to $50 \%$ and a porosity from 7 to $30 \%$, respectively. The second group contains ED Tuff with $0.29 \mathrm{~kg} / \mathrm{m}^{2} \sqrt{ } \mathrm{h}$ (anisotropy of $36 \%$ and porosity of $25 \%)$ and $\mathrm{CH}$ with $0.37 \mathrm{~kg} / \mathrm{m}^{2} \sqrt{\mathrm{h}}(13 \%$ anisotropy and porosity of $8 \%$ ). The third group contains five tuff varieties from $2.54 \mathrm{~kg} / \mathrm{m}^{2} \sqrt{\mathrm{h}}$ for CA to 7.86 $\mathrm{kg} / \mathrm{m}^{2} \sqrt{\mathrm{h}}$ for GR. This group has an anisotropy ranging from $99 \%$ for TY to $4 \%$ for RP and porosities from 5 to $42 \%$, respectively. The last group consists of only one rock, $\mathrm{WB}$, with a high average absorption value of more than $15 \mathrm{~kg} / \mathrm{m}^{2} \sqrt{ } \mathrm{h}$. This tuff has an anisotropy of $1.5 \%$ and a porosity of $37 \%$.

\section{Water vapour diffusion}

The values of water vapour diffusion range between 130.27 and 7.27. The highest water vapour resistance was measured for $\mathrm{CF}$ with an average value of 93.05 and an anisotropy of $46 \%$, followed by $\mathrm{CH}$ with nearly 90 and an anisotropy of $50 \%$ and TY with 46.4 and anisotropy values of $72 \%$. The anisotropy values seem to be affected most probably by the clear layering of the rock (Table 2). Eight tuffs range between 20 and 10 and only three samples have a water vapour diffusion value $<10$ (Table 2).

For the chosen rock samples, the highest water vapour resistance $(\mu)$ was measured for TY with 46.4 , accompanied by a high anisotropy of $72 \%$. Only one of these samples has a vapour resistance value $>20$ (HW) and a moderate anisotropy of $15 \%$. Five of the samples (ED, $\mathrm{HW}, \mathrm{RP}, \mathrm{HD}, \mathrm{BT}$ and $\mathrm{BP}$ ), comprising the majority, have $\mu$ values between 10 and 20 with an anisotropic behaviour between 15.5 and $49 \%$. Only CA has a $\mu$ value $<10$ with a low anisotropy of $6 \%$.

\section{Swelling pressure}

LS reached the lowest swelling pressure of only 0.005 MPa. On the other hand, two samples reached medium swelling pressure values of 0.015 (BT) and $0.03 \mathrm{MPa}(\mathrm{BP})$. However, $\mathrm{CA}$, with the lowest dilatation value, does not show the lowest swelling pressure value with $0.011 \mathrm{MPa}$. All results show a clear correlation, the swelling pressure measurements suggest that there is relationship between the obtained moisture expansion results and those obtained by the swelling pressure experiments. A particular case represents LS with low swelling pressure values but contrasting relative high hydric dilatation (Fig. 9).

In general, the swelling pressure is relatively low and well below the splitting tensile strength (between 0.005 and $0.03 \mathrm{MPa}$ ). It can be assumed that swelling and contraction as a result of drying and wetting has an effect on deterioration even when the pressure induced is low.

\section{Sorption and saturation degree}

Hygroscopic water sorption was measured between 20 and $95 \% \mathrm{RH}$ by $30{ }^{\circ} \mathrm{C}$ in a climatic chamber. The measurements were carried out on drilling core slides with a diameter of $20 \mathrm{~mm}$ and thickness of $50 \mathrm{~mm}$, respectively. The amount of absorbed water is given per $\mathrm{g} / \mathrm{cm}^{3}$ of the tested material. We can divide the measured samples into three groups: low, middle and high hygroscopic water sorption. By far the highest level is shown by the samples from BP, LS, and TY. The first two stone types also show the highest amount of micropores with more than $90 \%$ (Table 2). The middle group includes the majority of the investigated tuffs $\left(0.02-0.05 \mathrm{~g} / \mathrm{cm}^{3}\right.$, Table 2$)$. The last group contains only three tuffs, which have sorption values of less than $0.01 \mathrm{~g} / \mathrm{cm}^{3}$. CF, with only $0.006 \mathrm{~g} / \mathrm{cm}^{3}$, shows the lowest saturation at $95 \% \mathrm{RH}$.

A clear tendency of correlation is observable between the amount of micropores and the saturation degree (Fig. 10). The highest sorption is shown by the samples that have the highest number of micropores. All volcanites show their highest saturation degrees at $95 \% \mathrm{RH}$.

\section{Splitting tensile strength and compressive strength}

Under dry conditions, all of the splitting tensile strength (STS) values vary between 0.99 and $10.65 \mathrm{MPa}$ (Table 4).

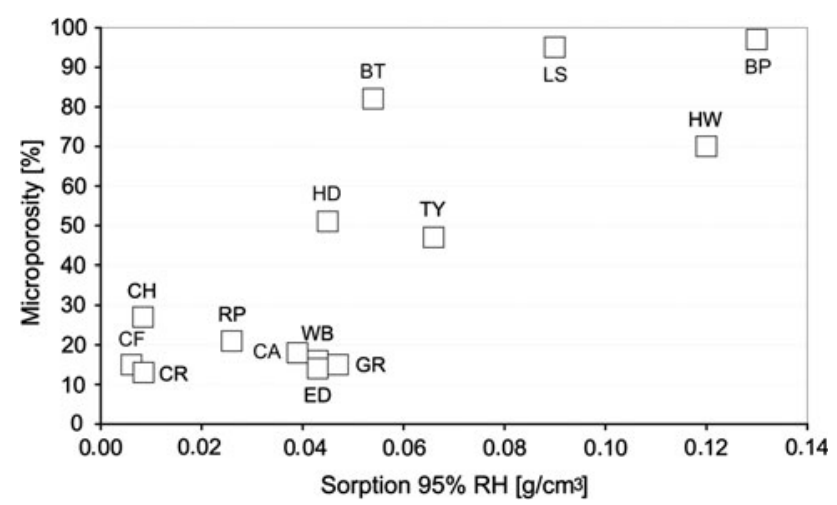

Fig. 10 Correlation of sorption by $95 \% \mathrm{RH}$ and the amount of microporosity 
The water-saturated samples reached values between 0.49 and 8.71 $\mathrm{MPa}$.

The resistance against tensile stresses of all kind of rocks, including the tuffs, is one of the most important parameters for all physical weathering processes. Especially if the stones have distinct layering and spatial orientation of any foliation or sedimentary layering, splitting tensile strength tests can help understand the role of binding forces between different components and expandable minerals, like some clay minerals (Siegesmund and Duerrast 2011). Of the 14 investigated tuffs, six have a clearly recognizable laminated (foliated) pyroclastic fabric (CA, BP, RP, BT, TY, and LS). The influence of this layering on mechanical stress is given by the anisotropic behaviour according to the splitting tensile strength. While the decrease in the measured values for RP with $33 \%$, followed by LS (24\%), HD (20\%), WB (17\%) and BP Tuff (15\%) alone reached critical values, the impact of anisotropy by water saturation changed dramatically for some samples, e.g. HD reached $63 \%$, HW $31 \%$, BP $22 \%$ and BT $20 \%$. The last two rocks show a clear layering. The highest splitting tensile strength reduction is observed for HD and CA (both $49 \%$ ) followed by BP (44\%) and the BT $(37 \%)$. Both lithic fragments and large porphyric crystals can also have an effect on the structural breakdown and the fractured surface. In the case of the Bufa Tuff, the fractures along the $X Y$ plane (parallel to the bedding) took place along the material boundary between the clearly oriented lithic components and the fine microcrystalline matrix. Lithic fragments can also control the occurrence of fractures in Cantera Amarilla Tuff. These fragments, mostly pumice, have a lower hardness than the matrix and are only partly connected to it (Jáuregui et al. 2012).

It is well known that water-saturated tuffs as well as other porous stone types have a lower strength than under dry conditions and that there is a correlation between the modulus of elasticity and the compressive strength (Toeroek et al. 2007). An average reduction of around $30 \%$ (ranging from 12-75\%) was observed in the 14 different tuffs (Table 4).

The compressive strength ranges from around $8.2 \mathrm{~N} / \mathrm{mm}^{2}$ for CA to $98.0 \mathrm{~N} / \mathrm{mm}^{2}$ for CF (see Table 5). For ten of the investigated samples, all directions were taken into consideration. Four of these ones only have a very low anisotropy, between only 0.1 and $8 \%$ (Table 5).

Table 4 Splitting tensile strength (STS) in dry and water-saturated conditions and the respective strength reduction

\begin{tabular}{|c|c|c|c|c|c|c|c|c|c|c|c|c|c|c|c|}
\hline Stone type & Direction & WB & ED & HW & $\mathrm{RP}$ & $\mathrm{HD}$ & BT & LS & $\mathrm{CR}$ & $\mathrm{CA}$ & TY & $\mathrm{CH}$ & GR & $\mathrm{BP}$ & $\mathrm{CF}$ \\
\hline \multirow{3}{*}{$\begin{array}{l}\text { Splittinge tensile strength dry } \\
\beta_{\mathrm{SZ}}(\mathrm{MPa})\end{array}$} & $X$ & $1.46^{\mathrm{a}}$ & $3.30^{\mathrm{b}}$ & $2.43^{\mathrm{a}}$ & $1.91^{\mathrm{a}}$ & 3.70 & 6.04 & 6.29 & 3.94 & 0.99 & 5.43 & 5.13 & 2.27 & 6.90 & 10.65 \\
\hline & $Z$ & $1.76^{\mathrm{a}}$ & & $3.23^{\mathrm{a}}$ & $2.85^{\mathrm{a}}$ & 4.62 & 6.95 & 8.25 & 4.02 & 1.05 & 5.71 & 5.61 & 2.24 & 5.89 & 9.89 \\
\hline & $\begin{array}{l}\text { Anisotropy } \\
(\%)\end{array}$ & 17 & - & 25 & 33 & 20 & 7 & 24 & 2 & 6 & 5 & 8.5 & 1 & 15 & 7 \\
\hline \multirow{3}{*}{$\begin{array}{l}\text { Splitting tensile strength } \\
\text { water saturated } \beta_{\mathrm{SZ}}(\mathrm{MPa})\end{array}$} & $X$ & $1.25^{\mathrm{a}}$ & $2.78^{\mathrm{b}}$ & $2.10^{\mathrm{a}}$ & $1.45^{\mathrm{a}}$ & 1.14 & 3.65 & 5.82 & 2.61 & 0.49 & 3.94 & 4.56 & 1.39 & 3.99 & 8.23 \\
\hline & $Z$ & $1.25^{\mathrm{a}}$ & & $3.07^{\mathrm{a}}$ & $1.77^{\mathrm{a}}$ & 3.1 & 4,57 & 6.69 & 3 & 0.56 & 4.12 & 4.79 & 1.58 & 3.11 & 8.71 \\
\hline & $\begin{array}{l}\text { Anisotropy } \\
(\%)\end{array}$ & 0 & - & 31.5 & 18 & 63 & 20 & 13 & 13 & 12.5 & 4 & 5 & 12 & 22 & 5.5 \\
\hline STS reduction $(\%)$ & $\varnothing$ & 22 & 37 & 9 & 32 & 49 & 37 & 14 & 30 & 49 & 26 & 13 & 34 & 44 & 18 \\
\hline Reduction (\%) & $X$ & 29 & - & 5 & 38 & 16 & 24 & 7 & 34 & 43 & 16 & 11 & 39 & 42 & 23 \\
\hline Reduction (\%) & $Z$ & 14 & - & 13.5 & 24 & 75 & 47 & 19 & 25 & 53 & 28 & 15 & 29 & 47 & 12 \\
\hline
\end{tabular}

a Stueck (2006)

b Stueck et al. (2008)

Table 5 Uniaxial compressive strength (UCS) in dry conditions $\left(\mathrm{N} / \mathrm{mm}^{2}\right)$

\begin{tabular}{|c|c|c|c|c|c|c|c|c|c|c|c|c|c|c|}
\hline Direction & WB & ED & HW & $\mathrm{RP}$ & HD & BT & LS & $\mathrm{CR}$ & $\mathrm{CA}$ & TY & $\mathrm{CH}$ & GR & $\mathrm{BP}$ & $\mathrm{CF}$ \\
\hline$X$ & $18-19.3^{\mathrm{a}}$ & - & $14-60^{\mathrm{b}}$ & $56^{c}$ & 37.24 & 66.69 & 74.26 & 31.9 & 9.45 & 50.82 & 91.94 & 17.25 & 66.07 & 95.60 \\
\hline$Y$ & & - & & & 39.84 & 64.34 & 66.9 & 29.94 & 8.21 & 50.86 & 83.2 & 16.58 & 62.23 & 94.30 \\
\hline$Z$ & & - & & & 32.04 & 59.59 & 57.98 & 32.56 & 9.72 & 50.82 & 90.58 & 18.08 & 53.67 & 98.04 \\
\hline Anisotropy (\%) & - & - & - & - & 20 & 11 & 22 & 8 & 15 & 0.1 & 21 & 8 & 19 & 4 \\
\hline
\end{tabular}

a Mueller (1987)

${ }^{\mathrm{b}}$ Haberland (2006)

c Vereinigte Porphyrbrueche auf dem Rochlitzer Berge GmbH 


\section{Discussion and conclusion}

Contrary to many other rock types, most of the volcanic rocks are formed during a relatively short period of time. The development can be divided into two main processes: lava cools down at the surface or sedimentation of volcanic ash and rock fragments are ejected during a volcanic eruption (tuffs).

The matrix of the investigated tuff rocks consists principally of fine sand up to clay sized pyroclastic material (mostly volcanic ash and pumice) distributed and packed in very different ways, depending on the extrusion type. In the case of the extrusive igneous rock types, the material cools down so quickly that crystallisation does not occur or is incomplete. The resulting ash particles and glass shards of the tuffs show mostly irregular sharp edges, angular to very angular grain and fragment shapes and consequently a poorly or weakly welded matrix (Figs. 4, 5). This fact allows the formation of a very complex system of pore networks defined by macroporosity and microporosity. The different constituents of pyroclastic rocks in particular can show a layered and laminated texture, which induced a distinct anisotropy in terms of its petrophysical, mechanical and moisture properties. Thus the rock fabric plays a very important role in the behaviour of the rock to moisture and weathering and controls its petrophysical properties (Siegesmund and Duerrast 2011).

Water transport and uptake took place due to the capillary active pores. Compared with the microporosity, the averaged $w$ value should show a weak correlation (Fig. 11). The microporosity and the $w$ value are compared in Fig. 11a. In general, samples with a high microporosity have a lower $w$ value.

\section{Swellable clay minerals content based on XRD and $\mathrm{CEC}$ results}

In spite of the comprehensive investigations we carried out, the real cause for the moisture expansion observed, either under hygric or hydric conditions, remains unclear. It is most likely due to an interaction between different processes (Ruedrich et al. 2011).

XRD quantification of clay minerals, particularly in volcanic rocks, is demanding work (Moore and Reynolds 1997; Dohrmann et al. 2009). The application of the Rietveld method is complicated when unknown amounts of glass are present. Nonetheless, the CEC method could be used as an approximation to determine if expandable clay minerals are dominant or not (Dohrmann and Kaufhold 2010). Ruedrich et al. (2011) discussed the different CEC values of the individual clay minerals and the use of the measured CEC values of the rock samples for the semi-
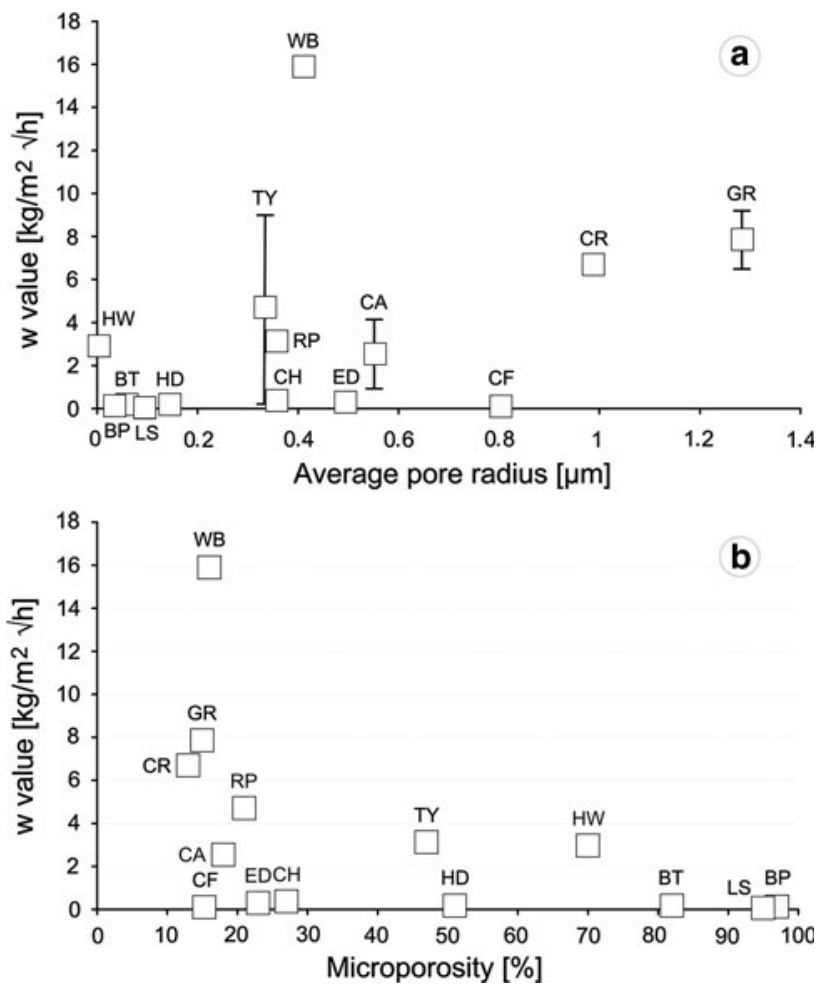

Fig. 11 a Correlation of the $w$ value and the average pore. b Correlation of the $w$ value and the microporosity

quantitative approximation of the smectite contents. The unit of the CEC value is milliequivalent per $100 \mathrm{~g}$ (meq/ $100 \mathrm{~g})$.

The CEC values listed in Table 1 for the eight selected samples range from 0.7 (HD) to $17.6(\mathrm{TY})$.

The TY, ED, BP, HW, and CA samples (Fig. 12) contain smectites, as verified by ethylene glycol intercalation (EG) of separated $<2 \mu \mathrm{m}$ fractions. BT also expanded upon EG treatment, however, the smectitic interlayers are part of two different types of illite-smectite mixed layers, as verified by thermal treatment $\left(375^{\circ} \mathrm{C}\right.$ : all interlayers were collapsed to $10 \AA$ ). HD contains very small amounts of smectitic interlayers, the dominating clay minerals are very close to pure illite (R3 illite(0.95)-smectite mixed layers). $\mathrm{RP}$, on the other hand, did not expand at all after EG treatment.

The CEC is highest for the TY, HW, and BP tuff (16-18 meq/100 g), reflecting the highest smectite content of approximately $15-20 \mathrm{wt} \%$ at least for TY and HW. The large CEC of BP can partly also be explained by clinoptilolite, a mineral of the zeolite group. Zeolites are also known for their large CEC values (for discussion and problems with these CEC values see Dohrmann et al. 2012).

ED has also a high CEC value of $10 \mathrm{meq} / 100 \mathrm{~g}$ reflecting approximately $10 \mathrm{wt} \%$ smectite. Smectite was 


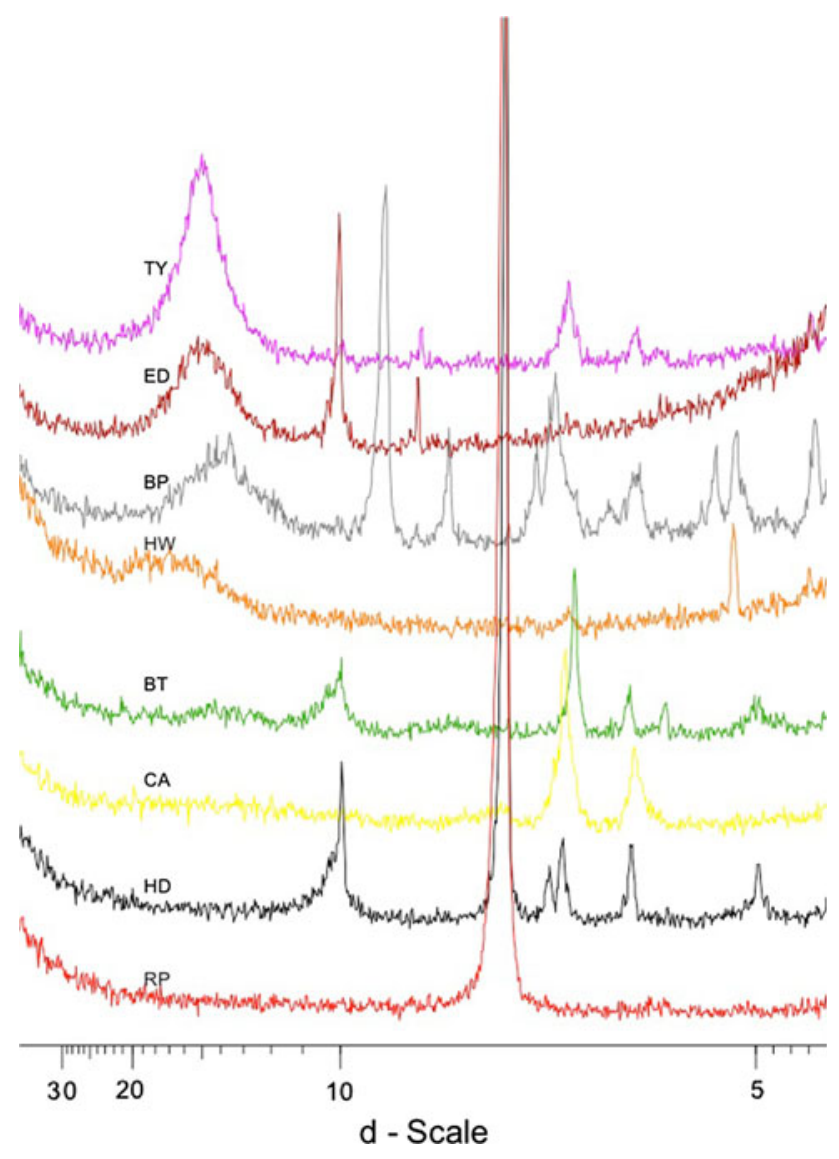

Fig. 12 X-ray diffraction patterns of whole rock tuff samples

also confirmed by EG expansion in CA, which contains based on the CEC approximation ca. $5 \mathrm{wt} \%$ smectite. BT has lower amounts of smectitic layers (ca. $3 \%$ ) in mixed layer minerals of different ordering types, whereas the amounts of smectitic layers are very low in the HD sample $(<1 \mathrm{wt} \%)$. RP does not contain smectite at all and the low CEC value of $1 \mathrm{meq} / 100 \mathrm{~g}$ can be explained by the large kaolinite content.

\section{Moisture expansion as a function of the CEC value}

In the present study, there is no clear correlation between the CEC values and the moisture expansion (Fig. 13). No correlation between the whole set of CEC values and the hydric expansion could be identified, however, for samples with CEC values $<10 \mathrm{meq} / 100 \mathrm{~g}$ (low smectite contents) a trend is visible (Fig. 13). Some of these samples show a pronounced anisotropic behaviour, in the case of water transport properties or mechanical strength, which can probably be traced back to the fabric characteristics, e.g. the large clasts of CA and the layering in BT. BP, HW, and TY have the highest CEC values, between 15.6 and $17.6 \mathrm{meq} / 100 \mathrm{~g}$ (Fig. 13), but they do not really show

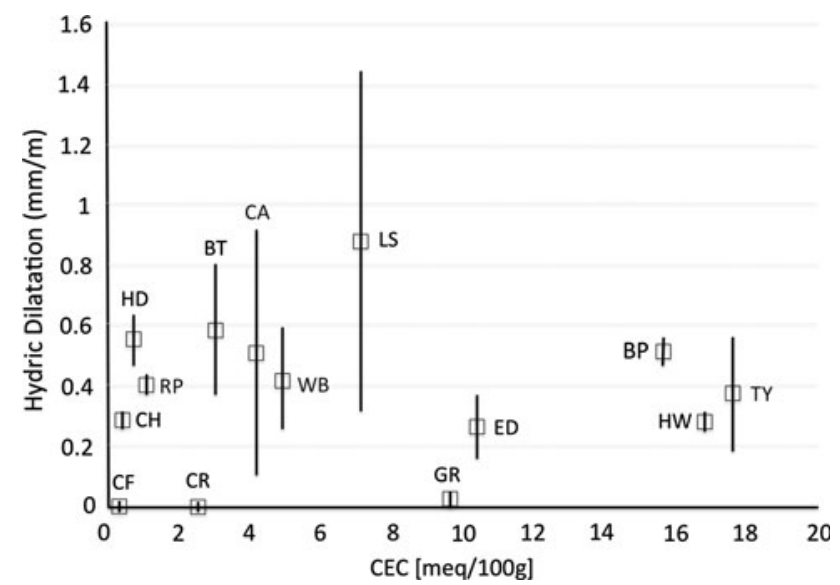

Fig. 13 Moisture expansion and the CEC value do not show a clear correlation

significant expansion, although they have a high amount of smectite. These three tuffs showed medium to high averaged splitting tensile strength values between 2.83 and 6.39 $\mathrm{MPa}$, which probably influence the expected higher moisture expansion (Table 4). Two of the investigated tuff rocks (GR, ED) have a substantial CEC value (around $10 \mathrm{meq} / 100 \mathrm{~g}$ ), but a similarly low hydric dilatation (Fig. 13).

\section{Moisture expansion as a function of the microporosity and average pore radius}

In contrast to the relation between the CEC value and moisture expansion, there is an obvious correlation between the microporosity and the hydric expansion (Fig. 14a). In particular, a correlation can be detected for the hydric expansion on the $X$ and $Y$ axes, probably because the swelling process is not affected by layering and lamination (Fig. 14b).

Most of the studied rocks show a correlation between the average pore radius and the hydric moisture expansion values. In general, it can be observed that a decrease of the hydric dilatation occurs with the increase of the average pore radius, which is clearly recognizable in Fig. 15.

\section{Softening properties as a function of moisture content}

Weathering often occurs in the base area of historical constructions erected of volcanic stones (Yavuz 2006; Wedekind et al. 2011; Jáuregui et al. 2012). One reason for deterioration is due to the decrease in strength upon wetting of the rock, described by Hirschwald (1908) as "softening". The softening degree varies among the different lithotypes. For crystalline rocks, such as granites and 

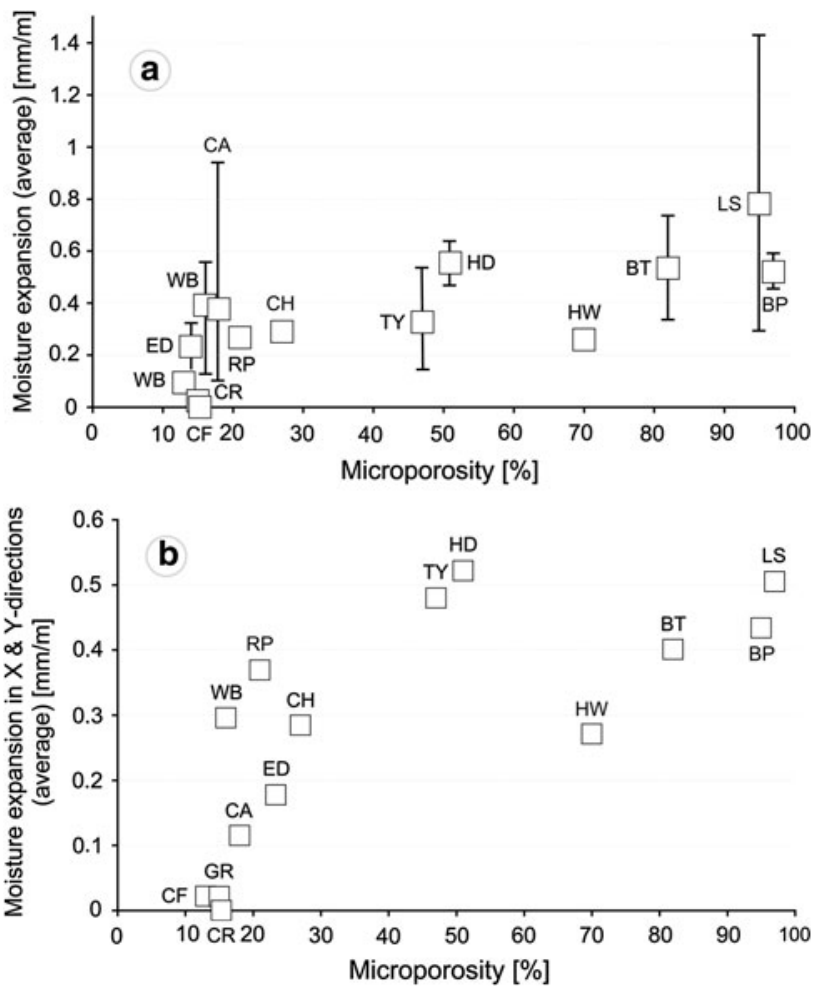

Fig. 14 a Moisture expansion and the microporosity show a distinct tendency of correlation. b Moisture expansion on the $X$ and $Y$ axes shows a clear correlation

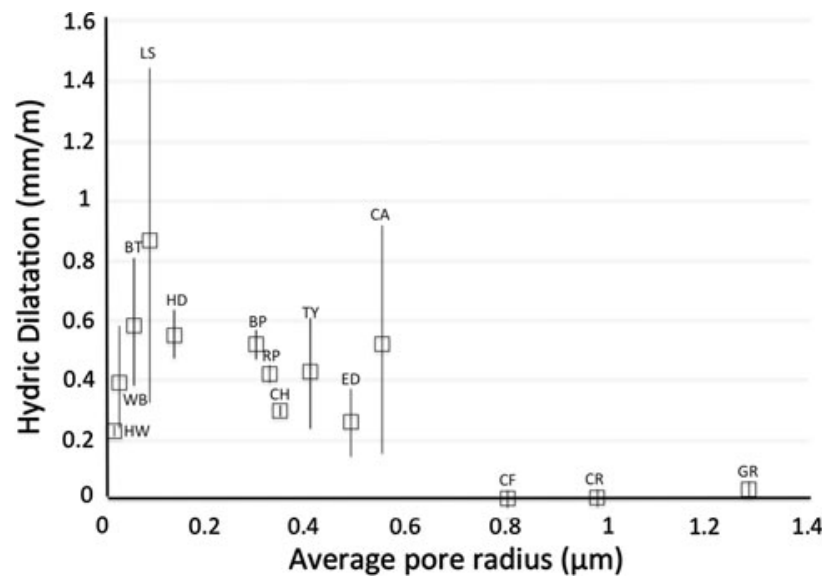

Fig. 15 Moisture expansion and the average pore radius show a tendency of correlation

gneisses, the softening effect is minimal. However, this effect can be significant in porous rocks such as sandstones and tuffs, and can reach a strength decrease of up to $50 \%$ (Siedel 2010; Jáuregui et al. 2012). Morales Demarco et al. (2007) found a positive correlation between the decrease of the compressive strength and the magnitude of moisture expansion in sandstones. This correlation has been verified for the tensile strength of sandstones in Ruedrich et al. (2011).

For the weakening and decay of stones, the stress induced by weathering processes has to exceed the rock strength. One of the most useful methods to determine this strength is the tensile strength, because this property is significantly lower compared to the compressive strength. This strength is mainly controlled by the porosities as presented in Fig. 16 for the $Z$ and $X$ direction.

The analyzed tuffs show a weak correlation between the moisture expansion and the reduction of the splitting tensile strength, especially for the $X$ direction (Fig. 16b). In this case, the dilatation due to the effects of moisture causes a weakening and softening of the rock, particularly under water-saturated conditions, which is shown for the $X$ and $Z$ axes (Fig. 16a, b). Moisture expansion and the STS-value in the $Z$ direction give evidence of a weak correlation for most of the samples (Fig. 17a). The graph for the strength versus the expansion in the $X$ direction only shows an undefined point cloud (Fig. 17b).

\section{Moisture expansion related to the physical properties}

The fabric of a rock affects the petrophysical properties (Siegesmund and Duerrast 2011). One key factor is the pore size distribution, which affects the stone's durability (Punuru et al. 1990; Fitzner and Basten 1994; Benavente et al. 2004). Ruedrich et al. (2011) found that the effect of the disjoining pressure is relevant in rocks with a high amount of micropores. In fact, tuffs like HW, HD, BT, LS, $\mathrm{TY}$ and BP have a significant portion of micropores (50\% or more). These samples also show the highest values of hydric dilatation, especially on the $Z$ axis (Fig. 14a). Especially HD, which has a very low CEC value, shows an important dilatation. In this case, the dilatation is controlled exclusively by the microporosity and its dense and complex pore network that is associated to the layering of the tuff. This observation points to the disjoining pressure as a major factor affecting moisture expansion (Fig. 5, Hilbersdorf Tuff, c).

Our investigations demonstrate that, besides the clay minerals, the microporosity has a significant effect on swelling and moisture expansion. Ruedrich et al. (2011) suggest the importance of the relation between clay mineral content, porosity and the location of the clay minerals within the pore space. The influence of the swelling depends on the clay minerals if they are oriented along the grain boundaries. However, if the tuffs contains high amounts of clay minerals but the pores are too large, i.e. the pore walls are only coated by the clay minerals, then the swelling pressure induced by the clay minerals will not have any significant effect on the moisture expansion, as 

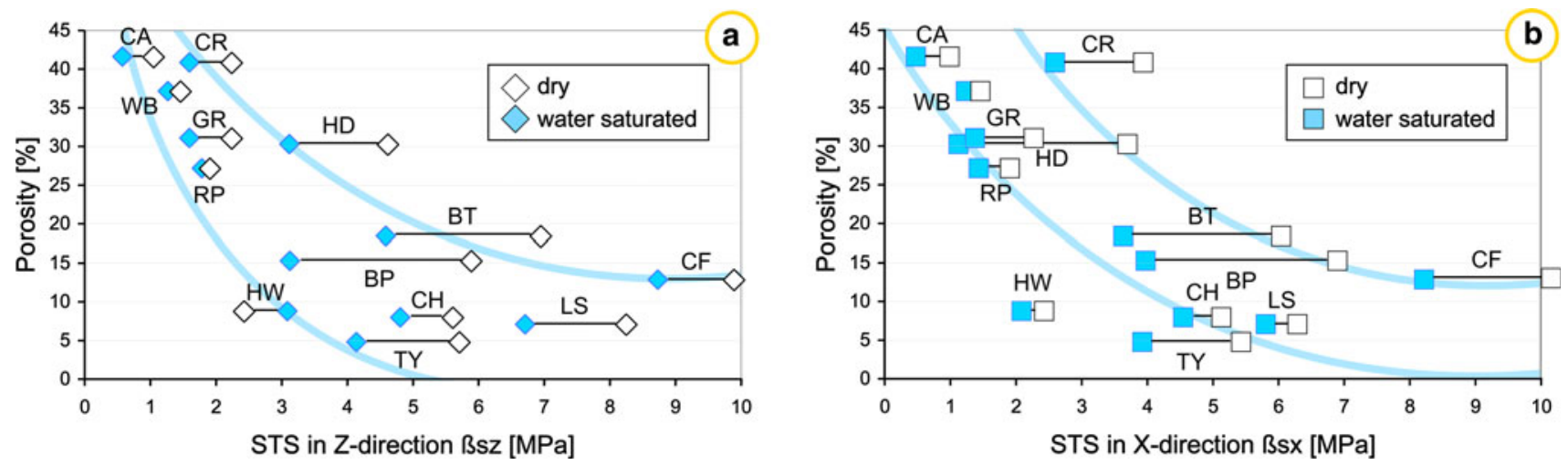

Fig. 16 Correlation between the splitting tensile strength (STS) and the effective porosity. a Correlation on the $Z$ axis and $\mathbf{b}$ on the $X$ axis
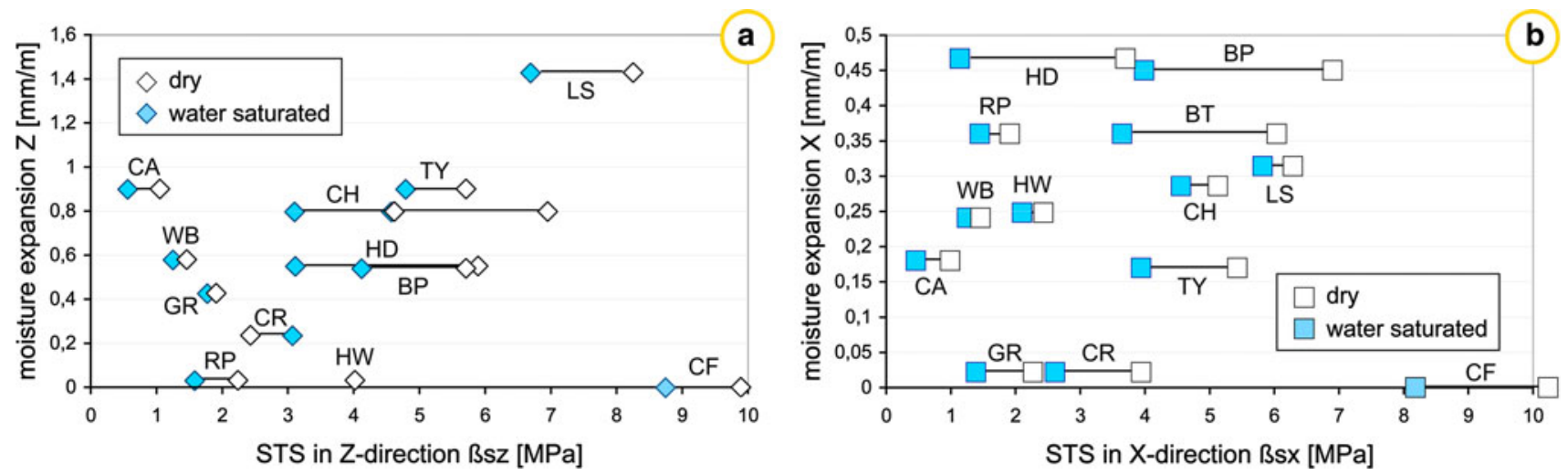

Fig. 17 The splitting tensile strength and moisture expansion show a weak correlation $\mathbf{a}$ in the $Z$ direction and $\mathbf{b}$ in the $X$ direction under dry conditions only (b)

was clearly demonstrated by SEM-observations made of BP, HW, TY, and ED (Fig. 18). Reyes-Zamudio et al. (2011), and Ruedrich et al. (2011) were also able to show that rocks with a higher amount of clay minerals and larger pores do not show higher moisture expansion. BT seems to be a special case. The SEM images show other iron-rich minerals besides the presence of some clay minerals (Fig. 19a, b). The observed dilatation in this tuff may also be associated with an expansion due to the oxidation and crystallisation of these minerals (Fig. 19c).

In general, hydric and hygric swelling in porous rocks were discussed due to swellable clay minerals. Different hypotheses, like inner-crystalline or osmotic swelling, are the leading hypotheses. However, both theories would require that the clay minerals be responsible for a higher CEC value, and lastly, that they be correlated to greater moisture expansion.

However, our extensive investigation on tuffs with a broad variation in mineralogy and rock fabrics shows that the above-mentioned correlation cannot be supported. At first, the total amount and type of clay minerals are also of critical importance. A detailed clay mineral study is absolutely necessary to explain the observed moisture expansion.

1. We were able to show that the amount of microporosity has a significant impact on the intensity of the moisture expansion. Tuffs with a higher amount of microporosity show a higher moisture expansion, even when the swellable clay minerals are lacking.

2. The study also demonstrated that there is a clear correlation between the amount of moisture swelling and the softening of the tuffs, as well as the pore size and the degree of water saturation.

3. There is no doubt that the clay minerals can significantly contribute to moisture expansion, but not all of the moisture-related expansion can be attributed to the presence and amount of the minerals of this group. The influence of clay minerals is noticeable in the case of fine laminated varieties showing a high anisotropy on moisture transport properties and mechanical strength. 

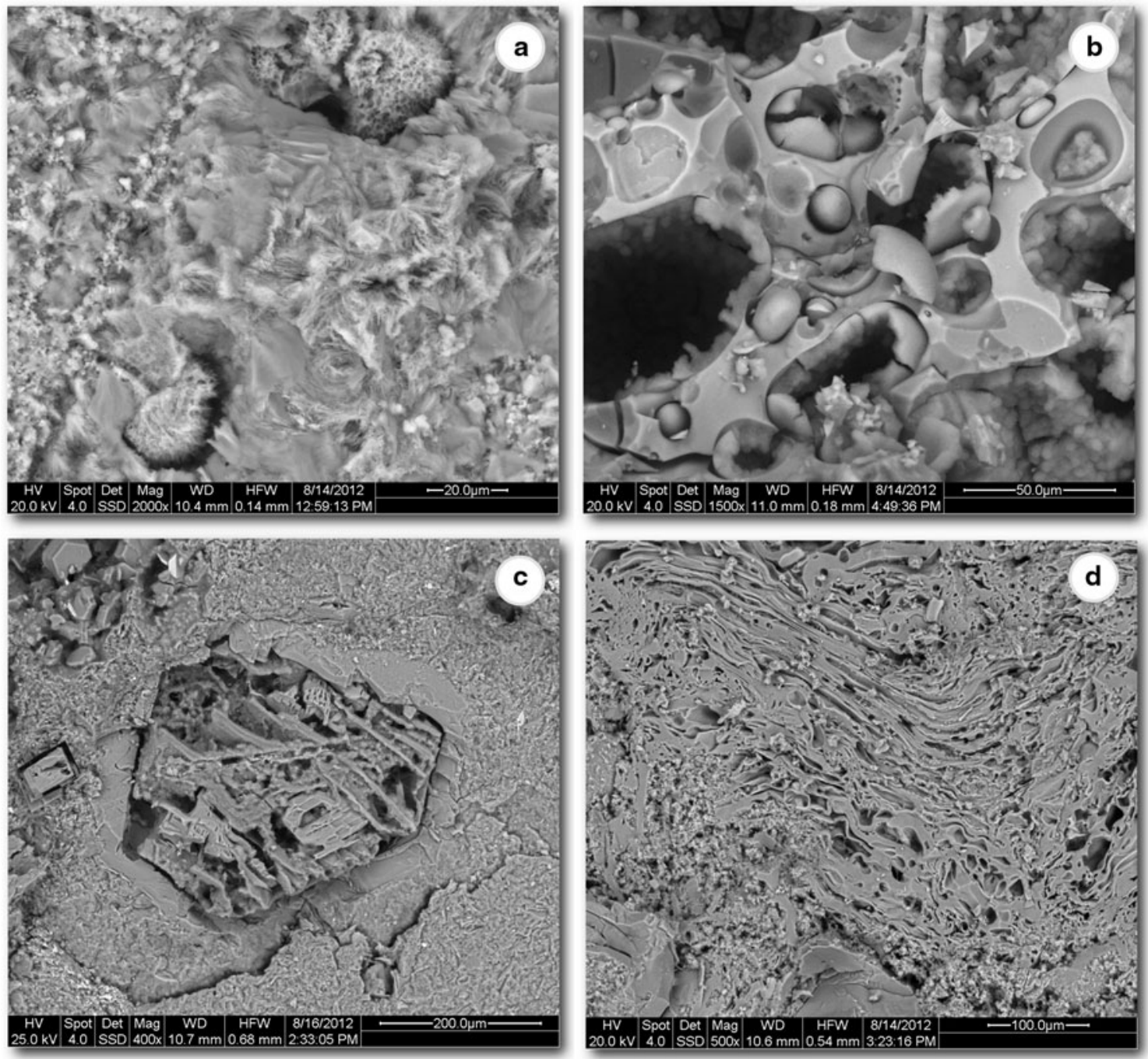

Fig. 18 a SEM images of Blanca Pachuca Tuff (BP) with partly filled pores. b The Habichtswald Tuff (HW), with a clay rich pore space coating out of smectite. c Inner structure of the Tenayocátetl

Tuff (TY) shows altered minerals covered with a fine coating of smectite (plagioclase in the middle) d Eger-Demjén Tuff (ED) with long drown-out pores
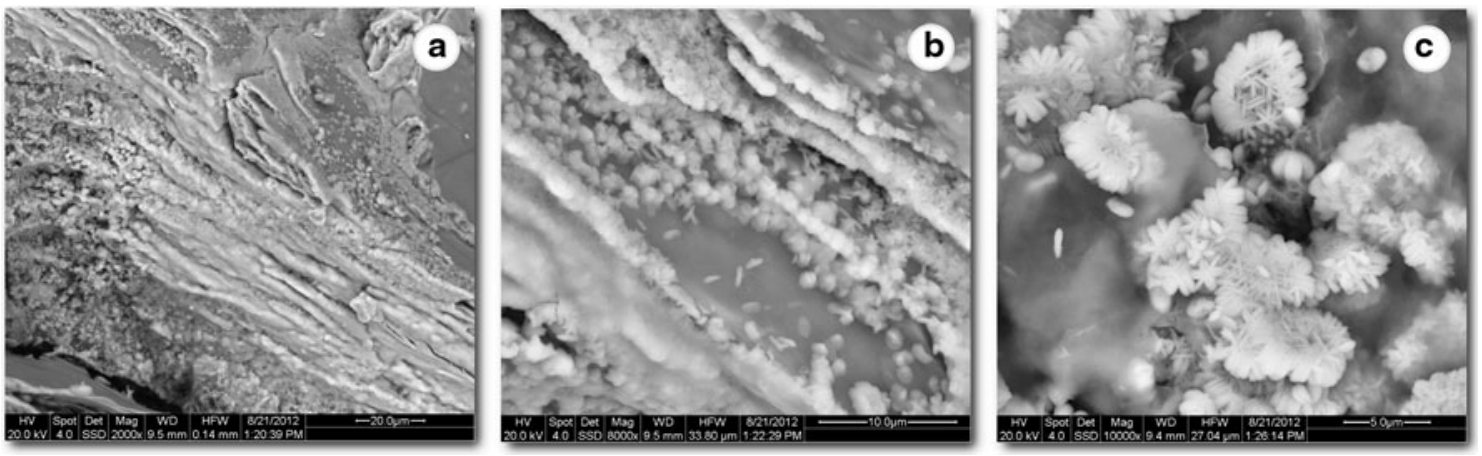

Fig. 19 a Bufa Tuff (BT) with oriented iron-rich minerals. b Recrystallisation of Fe-oxide on the surface. c Close-up view with well-crystallized Fe-oxides

4. The importance of the disjoining pressure may have been overlooked in the literature on moisture expansion. A high moisture expansion was clearly demonstrated in the case of some tuffs, which were more or less devoid of any clay minerals showing CEC values lower than $1.0 \mathrm{meq} / 100 \mathrm{~g}$. 
In summary, it is undoubtedly clear that not only clay minerals may affect the swelling pressure, and that quiet complex processes of mineralogical aspects and rock fabrics, like microporosity and the interaction of moisture films, have to be considered.

Acknowledgments We are grateful to Detlev Klosa of the BGR for the SEM images, and Ch. Gross for their help and useful discussion. Our work was supported by the DAAD, German Science Foundation (DFG Si-438/44-1) and the Hans-Boeckler-Foundation.

Open Access This article is distributed under the terms of the Creative Commons Attribution License which permits any use, distribution, and reproduction in any medium, provided the original author(s) and the source are credited.

\section{References}

Auras M, Steindlberger E (2005) Verwitterung und Festigung vulkanischer Tuffe. $\mathrm{Z}$ dt Ges Geowiss 156:167-175

Benavente D, García del Cura MA, Fort R, Ordóñez S (2004) Durability estimation of porous building stones from pore structure and strength. Eng Geol 74:113-127

Buchanan LJ (1980) Ore-controls of a fossil geothermal system: the Las Torres Mine, Guanajuato, Mexico, private report

De La Calle C, Suquet H (1988) Vermiculite. In: Bailey SW (ed) Hydrous phyllosilicates. Reviews in mineralogy, vol 19. Mineralogical Society of America, Washington DC, pp 455-496

Derjaguin BV, Obukov EV (1936) Anomalien dünner Flüssigkeitsschichten III Acta Physicochim. URSS 5(1):1-22

Dixon JB, Weed SB (1989) Minerals in soil environments, 2nd edn. Soil Science Society of America, Madison, p 1244

Dohrmann R, Kaufhold S (2010) Determination of exchangeable calcium of calcareous and gypsiferous bentonites. Clays Clay Miner 58:513-522

Dohrmann R, Rüping KB, Kleber M, Ufer K, Jahn R (2009) Variation of preferred orientation in oriented clay mounts as a result of sample preparation and composition. Clays Clay Miner 57:686-694

Dohrmann R, Genske D, Karnland O, Kaufhold S, Kiviranta L, Olsson S, Plötze M, Sandén T, Sellin P, Svensson D, Valter M (2012) Interlaboratory CEC and exchangeable cation study of bentonite buffer materials: II. Alternative methods. Clays Clay Miner 60:176-185

Edwards JD (1956) Estudio sobre algunos de los Conglomerados Rojos del Terciario Inferior del centro de México, XX Congreso Geológico Internacional, México

Fischer RV (1961) Proposed classification of volcaniclastic sediments and rocks. Geol Soc Am Bull 80:1-8

Fitzner B, Basten D (1994) Gesteinporosität-Klassifizierung, messtechnische Erfassung und Bewertung ihrer Verwitterungsrelevanz. In: Snethlage R (ed) Jahresberichte Steinzerfall-Steinkonzervierung 1992. Ernst and Sohn, Berlin, pp 19-32

Graf v, Reichenbach H, Beyer J (1995) Dehydration and rehydration of vermiculites: II Phlogopitic Ca-vermiculite. Clay Miner 30:273-286

Greiner W, Neise L, Stöcker H (1995) Thermodynamics and statistical mechanics. Springer, Berlin, p 101

Haberland D (2006) Zum Tragverhalten von Mauerwerk aus Nordhessischem Tuffstein. Denkmalgestein Tuffstein, IFS-report no. 22:35-45

Heim D (1990) Tone und Tonminerale: Grundlagen der Sedimentologie und Mineralogie. Enke Verlag, Stuttgart, p 157
Hirschwald J (1908) Die Prüfung der natuerlichen Bausteine auf ihre Wetterbeständigkeit. Z.-prakt. Geologie 2:60-66

Hockmann A, Kessler DW (1950) Thermal and moisture expansion studies of some domestic granites. US Bur Stand J Res 44:395-410

Jáuregui K, Wedekind W, Siegesmund S (2012) Weathering, conservation and restoration of the Santa Mónica church in Guadalajara, Mexico. In: Proceedings of the 12th international congress on deterioration and conservation of stone, Columbia University, New York, 22-26 Oct 2012 (in print)

Jimenez Gonzalez I, Scherer G (2004) Effect of swelling inhibitors on the swelling and stress relaxation of clay bearing stones. Environ Geol 46:364-377

Klopfer H (1985) Feuchte. In: Lutz P, Jenisch R, Klopfer H et al (eds) Lehrbuch der Bauphysik. Teubner Verlag, Stuttgart

Kocher M (2005) Quelldruckmessungen und thermische Druckmessungen an ausgewählten Sandsteinen. University Munich, Diss

Larsen TD, Cady PD (1969) Identification of frost susceptible particles in concrete aggregates, National Cooperative Research Program, Report 66. Highway Research Board, Washington DC

Le Maitre RW, Streckeisen A, Zanettin B (eds) (2004) Igneous rocks: a classification and glossary terms. Cambridge University Press, Cambridge

López-Doncel R, Wedekind W, Dohrmann R, Siegesmund S (2012) Moisture expansion associated to secondary porosity: an example of the Loseros Tuff Guanajuato, Mexico. Environ Earth Sci. doi:10.1007/s12665-012-1781-1

Lukas R (1990) Die Naturwerksteine Baden-Wuerttembergs und ihre Wetterbestaendigkeit sowie Verwitterungsprofile ausgewählter Carbonatgesteine. Diss University, Munich

Madsen FT (1976) Quelldruckmessungen an Tongesteinen und Berechnung des Quelldrucks nach der DLVO-Theorie, vol 108.-Mitteilungen des Institutes fuer Grundbau und Bodenmechanik, ETH Zuerich, p 65

Madsen FT, Mueller-Vonmoos M (1988) Das Quellverhalten der Tone, vol 133:S.-Mitteilungen des Institutes für Grundbau und Bodenmechanik, ETH Zürich, pp 39-50

Madsen FT, Mueller-Vonmoos M (1989) The swelling behaviour of clays. Appl Clay Sci 4:143-156

Madsen FT, Neuesch R (1990) Langzeitquellverhalten von Tongesteinen und tonigen Sulfatgesteinen, vol 140.-Mitteilungen des Institutes fuer Grundbau und Bodenmechanik, ETH Zuerich, p 51

Moore DM, Reynolds RC Jr (1997) X-ray diffraction and the identification and analysis of clay minerals. Oxford University Press, Oxford, p 332

Morales Demarco M, Jahns E, Ruedrich J, Oyhantcabal P, Siegesmund $S$ (2007) The impact of partial water saturation on rock strength: an experimental study on sandstone. $\mathrm{Z}$ dt Ges Geowiss Band 158:869-882

Mueller F (1987) Vulkanischer Tuff: Weiberner Tuff. Internationale Natursteinkartei

Nielsen LF (1994) Pore size distribution and shrinkage of porous material as related to moisture sorption. Technical Report 316, Building Materials Laboratory, Technical University of Denmark

Punuru AR, Chowdhury AN, Kulshreshtha NP, Gauri KL (1990) Control of porosity on durability of limestone at the Great Sphinx. Egypt Environ Geol 15(3):225-232

Reyes-Zamudio V, Angeles-Chávez C, Cervantes J (2011) Clay minerals in historic buildings. J Therm Anal Calorim 104(2): 405-413

Ruedrich J, Siegesmund S (2006) Fabric dependence of length change behaviour induced by ice crystallisation in the pore space of natural building stones. In: R Fort, M Alvarez de Buergo, M Gomez-Heras (eds) Heritage, weathering and conservation. Taylor \& Francis, London, 497-505 
Ruedrich J, Bartelsen T, Dohrmann R, Siegesmund S (2011) Moisture expansion as a deterioration factor for sandstone used in buildings. Environ Earth Sci 63:1545-1564

Schuh H (1987) Physikalische Eigenschaften von Sandsteinen und ihren verwitterten Oberflächen, vol 6:S. Münchner Geowiss. Abh., Enke Verlag, Stuttgart, p 66

Siedel H (2010) Historic building stones and flooding: changes of physical properties due to water saturation. J Perform Constr Facil 24:452-461

Siegesmund S, Duerrast H (2011) Physical and mechanical properties of rocks. In: Siegesmund S, Snethlage $\mathrm{R}$ (eds) Stone in architecture: properties, durability, 4th edn. Springer, Berlin, pp 97-225

Snethlage R (1984) Steinkonservierung. Arbeitsheft Bayer. Landesamt f. Denkmalpflege, 22, Munich

Snethlage R, Wendler E (1997) Moisture cycles and sandstone degradation. In: Baer NS, Snethlage R (eds) Saving our architectural heritage, the conservation of historic stone structures, Elsevier, Chichester, pp 7-24

Snethlage R, Wendler E, Klemm DD (1995) Tenside im Gesteinsschutz-bisherige Resultate mit einem neuen Konzept zur Erhaltung von Denkmälern aus Naturstein. In: Snethlage R (ed) Denkmalpflege und Naturwissenschaft-Natursteinkonservierung I. Verlag Ernst and Sohn, Berlin, pp 127-146

Steindlberger E (2003) Vulkanische Gesteine aus Hessen und ihre Eigenschaften als Naturwerksteine. Wiesbaden

Stueck H (2006) Materialeigenschaften und Verwitterungsprozesse bruchfrischer und konsolidierter Vulkanite. Diploma-thesis, University of Goettingen
Stueck H, Forgó LZ, Ruedrich J, Siegesmund S, Toeroek Á (2008) The behaviour of consolidated volcanic tuffs: weathering mechanisms under simulated laboratory conditions. Environ Geol 56:699-713

Timothy PW, Stratulat A, Duffus P, Prévost JH, George W, Scherer WG (2011) Flaw propagation and buckling in clay-bearing sandstones. Environ Geol 63:1565-1572

Toeroek Á, Forgó LZ, Vogt T, Loebens S, Siegesmund S, Weiss T (2007) The influence of lithology and pore-size distribution on the durability of acid volcanic tuffs, Hungary. In: Prikryl R, Smith BJ (eds) Building stone decay: from diagnosis to conservation, Geological Society, London, Special Publications 271:251-260

Tugrul A (2004) The effect of weathering on pore geometry and compressive strength of selected rock types from Turkey. Eng Geol 75:215-227

Wedekind W, Ruedrich J, Siegesmund S (2011) Natural building stones of Mexico-Tenochtitlán: their use, weathering and rock properties at the Templo Mayor, Palace Heras Soto and the Metropolitan Cathedral. Environ Earth Sci 63(7/8):1787-1798

Weiss T, Siegesmund S, Kirchner D, Sippel J (2004) Insulation weathering and hygric dilatation as a control on building stone degradation. Environ Geol 46(3-4):402-413

Wesche K (1977) Baustoffe fuer tragende Bauteile. 2nd edn, Bd. 1 Wiesbaden und Berlin, $\mathrm{p} 135$

Yavuz AB (2006) Deterioration of the volcanic kerb and pavement stones in a humid environment in the city centre of Izmir, Turkey. Environ Geol 51:211-227 